Article

\title{
New Eco-Sustainable Feed in Aquaculture: Influence of Insect-Based Diets on the Content of Potentially Toxic Elements in the Experimental Model Zebrafish (Danio rerio)
}

\author{
Cristina Truzzi ${ }^{1, *(\mathbb{D})}$, Federico Girolametti ${ }^{1, *(\mathbb{D})}$, Leonardo Giovannini ${ }^{2}$, Ike Olivotto ${ }^{1}$ (D), Matteo Zarantoniello ${ }^{1}$, \\ Giuseppe Scarponi ${ }^{1}$ (D), Anna Annibaldi ${ }^{1,3}$ and Silvia Illuminati $^{1}$
}

1 Department of Life and Environmental Sciences, Università Politecnica delle Marche, Via Brecce Bianche, 60131 Ancona, Italy; i.olivotto@univpm.it (I.O.); m.zarantoniello@pm.univpm.it (M.Z.); g.scarponi@univpm.it (G.S.); a.annibaldi@univpm.it (A.A.); s.illuminati@univpm.it (S.I.)

2 Independent Researcher, 06065 Passignano sul Trasimeno, Italy; leonardo.giovannini@outlook.it

3 Fano Marine Center, The Inter-Institute Center for Research on Marine Biodiversity, Resources and Biotechnologies (FMC), Viale Adriatico 1/N, 61032 Fano, Italy

* Correspondence: c.truzzi@univpm.it (C.T.); f.girolametti@pm.univpm.it (F.G.); Tel.: +39-071-2204981 (C.T.); +39-071-2204302 (F.G.)

check for updates

Citation: Truzzi, C.; Girolametti, F.; Giovannini, L.; Olivotto, I.; Zarantoniello, M.; Scarponi, G.; Annibaldi, A.; Illuminati, S. New Eco-Sustainable Feed in Aquaculture: Influence of Insect-Based Diets on the Content of Potentially Toxic Elements in the Experimental Model Zebrafish (Danio rerio). Molecules 2022, 27, 818. https://doi.org/10.3390/ molecules27030818

Academic Editor: Federico Maria Rubino

Received: 16 December 2021

Accepted: 21 January 2022

Published: 26 January 2022

Publisher's Note: MDPI stays neutral with regard to jurisdictional claims in published maps and institutional affiliations.

Copyright: (C) 2022 by the authors. Licensee MDPI, Basel, Switzerland. This article is an open access article distributed under the terms and conditions of the Creative Commons Attribution (CC BY) license (https:// creativecommons.org/licenses/by/ $4.0 /)$.

\begin{abstract}
According to the concept of circular economy, insects represent good candidates as aquafeed ingredients. Nevertheless, there are some potential chemical risks linked with insect consumption. In this study, we reared the teleost Danio rerio, used as an experimental model, with five experimental diets characterized by increasing levels $(0 \%, 25 \%, 50 \%, 75 \%$, and $100 \%)$ of full-fat Hermetia illucens (Hi) prepupae, substituting for fish meal (FM) and fish oil (FO). We investigated the presence of potentially toxic elements (PTEs) $\mathrm{Cd}, \mathrm{Pb}, \mathrm{Ni}, \mathrm{As}$, and $\mathrm{Hg}$ in larval (20 days), juvenile (2 months), and adult (6 months) fish. Quantitative determinations of $\mathrm{Cd}, \mathrm{Pb}, \mathrm{Ni}$, and As were made with an atomic absorption spectrometer; the total mercury content was determined by a direct mercury analyzer. The substitution of FM and FO with Hermetia illucens meal led to a reduction in the content of some PTEs, such as $\mathrm{Pb}$, As, and $\mathrm{Ni}$, in fishfeed, leading to concentrations below the legal limit of undesirable substances in animal feed. By increasing the Hi meal dietary content, we observed in the Danio rerio specimens an increase in $\mathrm{Cd}, \mathrm{Pb}$, and $\mathrm{Ni}$ content and a reduction in As content for all life stages. Moreover, a general increase in the content of $\mathrm{Cd}, \mathrm{Pb}, \mathrm{Hg}$, and $\mathrm{Ni}$ from larvae to juvenile was measured, while the shift of Danio rerio from the juvenile to the adult stage involved a significant increase in the content of $\mathrm{Pb}, \mathrm{Hg}$, and $\mathrm{Ni}$. Larvae had a reduced ability to bioaccumulate metal(loid)s compared to juveniles and adults. In conclusion, the content of PTEs in Danio rerio is influenced both by the type of diet administered and by the life stage of the animal itself. This research demonstrates the possibility of using Hi prepupae as an aquafeed ingredient without exposing fish to a chemical risk and, in perspective, allows applying these eco-sustainable diets for the breeding of edible fish species, without endangering human health.
\end{abstract}

Keywords: Hermetia illucens; cadmium; lead; arsenic; mercury; nickel; fish feed; aquaculture

\section{Introduction}

On the basis of a forecast predicting a significant demographic increase of the global population (over nine billion people by 2050), the Food and Agriculture Organization of the United Nations [1] estimates that world food production will have to increase by $60 \%$ to meet food needs. Therefore, we are facing the challenge of searching for feed and food with an adequate nutritional profile that "conserves land, water, plant and animal genetic resources, and it is environmentally non-degrading, technologically appropriate, economically viable and socially acceptable" [2]. Insects are a solid way to produce green feed, to reduce food waste, and to fight climate changes [3,4]. In fact, insects are rich in 
proteins and lipids, show a low environmental footprint [5], and can convert low-quality carbohydrate-rich organic materials (such as food waste) into high-quality feed ingredients to be used in feed formulas [6,7], thereby supporting the circular economy and sustainable development. In aquaculture, insects have been proposed to substitute for fish meal (FM) and fish oil (FO), obtained from wild-caught fish, due to the severe depletion of fish resources $[1,8,9]$. However, regarding the chemical hazard associated with fish feed, both FM and insects may contain hazardous chemicals, including potentially toxic elements, PTEs. It is known in fact that FM is an important source of PTEs in fish feed [10-14]. Fish meal is made by drying and grinding the carcasses of fish, leading to a concentration of toxic elements present in the fish themselves. This fact, together with the contamination of marine environments, led to a product that contains excessive amounts of pollutants [12] PTEs are naturally present in insects as well, but they can also be transferred to insects through the rearing substrate [15-17]. PTEs have a high degree of toxicity and a wide distribution in the environment [18-22]. Metals such as arsenic (As), nickel (Ni), cadmium $(\mathrm{Cd})$, lead $(\mathrm{Pb})$, and mercury $(\mathrm{Hg})$ rank among the priority elements that are of great public health significance. The International Agency for Research on Cancer (IARC) in fact classifies $\mathrm{Cd}$, $\mathrm{As}$, and $\mathrm{Ni}$ as carcinogenic, and $\mathrm{Pb}$ and $\mathrm{Hg}$ as probably carcinogenic to humans [23]. Consuming foods containing PTEs can lead to numerous human health risks, such as renal disfunction and cancer $(\mathrm{Cd})$ [24], neurological deficits $(\mathrm{Pb})$ [25], dementia and dysarthria (Hg) [26], cardiovascular disorders and skin problems (As) [27], DNA damage, and immunologic and neurologic problems (Ni) [28].

PTEs can be accumulated in aquatic organisms through different routes, including respiration and ingestion $[29,30]$. Nowadays, there is a growing recognition that dietary metal(loid) exposure may contribute to chronic toxicity in aquatic organisms [11,31-33]. These chemical contaminants can be bioaccumulated in organisms or biomagnified in food chains [34,35]. Therefore, the consumption of fish contaminated with PTEs poses a serious risk of exposure to these toxic elements and leads to a potential risk for human health [36-42]. Given their dangerous nature, concerning feed and food safety and, ultimately, human health, these PTEs are monitored both in the environment $[43,44]$ and in feed [45] and food [46-48]. Therefore, to achieve the safe production of insects to be used as feed in aquaculture, as well as investigate other substrates compatible with European rules regarding safety about chemical contaminants, a strict monitoring of PTEs content is necessary for all kind of feedstuff [49,50].

The Hermetia illucens (Hi, Diptera, Stratiomydae) has been proposed by the European Food Safety Authority Scientific Committee [3] as one of the species with the greatest potential as a food and feed ingredient in the European Union. It is characterized by a balanced essential amino acid profile, similar to that of FM, and represents a valuable protein source in fish diets $[9,51-53]$. Hi can bioaccumulate potentially toxic elements from the rearing substrate [15-17], but their content is generally lower than the legal limit for feed [45]. Therefore, Hi prepupae have been proposed as a substitute for FM in fish feed [54-59].

Danio rerio (zebrafish) is a perfect experimental model for scientific studies, because of its short life cycle, high reproductive rate, well-defined developmental processes, and abundant information on its genomic features, similar to that of vertebrates, including humans [60-64]. From an eco-toxicological perspective, zebrafish have been extensively used to study heavy metals, endocrine-disrupting chemicals, and persistent organic pollutants [65-69]. However, in most studies, high amounts of PTEs [69-75], which bear no relation to their content in the environment, were added to the fish feed or the aquatic environment, whereas studies wherein "natural" contaminants content were determined in zebrafish at various life stages are scarce $[32,33,76]$.

This study is part of the research project NUTRIFISH (Cariverona fundation, code n. 2017.0571), aimed at studying the possibility of including Hermetia illucens (Hi) meal, grown on substrates suitably enriched with polyunsaturated fatty acids (silverskin, coffee-roasting residue, and microalgae) in aquafeeds intended for aquaculture. In the 
present study, full-fat Hi prepupae meal was obtained from Hi larvae reared on a coffee by-product (coffee silverskin) enriched with $10 \%$ of microalgae Schizochytrium sp. [77]. The aim of this study is to evaluate the chemical risk associated with the use of Hi-based diets on PTEs content using zebrafish as an experimental model. In accordance with European directives [44,45], we evaluated the presence of $\mathrm{Cd}, \mathrm{Pb}, \mathrm{As}, \mathrm{Ni}$, and $\mathrm{Hg}$, in Danio rerio fed insect-based experimental diets from larvae to adults of zebrafish, in order to evaluate possible accumulation during the whole life cycle of the fish and to assess the possibility of applying these diets to commercial fish products normally used in human diet.

\section{Results}

\subsection{Potentially Toxic Elements in Water Tanks}

PTEs' total concentrations are reported in Table $1 . \mathrm{Hg}$ and $\mathrm{Pb}$ levels showed values below the instrumental LOD (0.6 and $30 \mathrm{ng} \mathrm{L}^{-1}$, respectively). As for other PTEs, the measured content was, from the lowest to the highest: $\mathrm{Cd}<\mathrm{As}<\mathrm{Ni}$. In general, the content of PTEs were well below the legal limits set by Italian Legislative Decree 31/2001 [43], which regulates the quality of water intended for human consumption in order to protect human health from the negative effects deriving from water contamination.

Table 1. PTEs levels in water tank compared to legal limits [43].

\begin{tabular}{ccc}
\hline Element & Determined Value $\left(\mu \mathbf{g ~ L}^{-\mathbf{1}}\right)$ & ${\text { Legal Limit }\left(\mu \mathbf{g ~ L}^{-\mathbf{1}}\right)}^{\mathrm{H}}$ \\
$\mathrm{Hg}$ & $<0.0006$ & 1 \\
$\mathrm{~Pb}$ & $<0.030$ & 25 \\
$\mathrm{Cd}$ & $0.008 \pm 0.001$ & 5 \\
$\mathrm{As}$ & $0.51 \pm 0.04$ & 10 \\
$\mathrm{Ni}$ & $3.3 \pm 0.5$ & 20 \\
\hline
\end{tabular}

\subsection{Potentially Toxic Elements in the Experimental Diets}

The PTEs content of diets used in the experimental design is shown in Table 2, as mg kg ${ }^{-1} \mathrm{ww}$ for a moisture level (M) of $12 \%$, for a comparison with legal limits of Directive 2002/32/EC [45] on undesirable substances in animal feed. PTEs content in Hi meal is also reported in Table 2 (from [16]) in support of the discussion of the results.

$\mathrm{Cd}$ content varied from 0.31 to $0.51 \mathrm{mg} \mathrm{kg}^{-1} \mathrm{ww}(12 \% \mathrm{M})$ (Table 2), corresponding to a range from 0.35 to $0.58 \mathrm{mg} \mathrm{kg}^{-1} \mathrm{dw}$, of the same order of magnitude as the content of $\mathrm{Cd}$ in the Hi prepupae used to prepare the insect meal $\left(0.20 \pm 0.02 \mathrm{mg} \mathrm{kg}^{-1} \mathrm{ww}\right.$, $12 \% \mathrm{M})$. A statistically significant decrease of Cd content was evidenced $(p=0.0022)$ in the Hi25 diet with respect to the Control diet, whereas the major inclusion of Hi meal substituting for FM led to a statistically significant increase of Cd content $(p=0.0022)$ in Hi50, Hi75, and Hi100 diets with respect to the Control diet and the Hi25 diet. Referring to the EC limit [45] on undesirable substances in animal feed, the mean value of Cd content, $0.42 \pm 0.08 \mathrm{mg} \mathrm{kg}^{-1} \mathrm{ww}(12 \% \mathrm{M})$, was lower than the legal limit for fish feed.

$\mathrm{Pb}$ content varied from 0.31 to $0.71 \mathrm{mg} \mathrm{kg}^{-1} \mathrm{ww}(12 \% \mathrm{M})$ (Table 2), corresponding to a range from 0.35 to $0.81 \mathrm{mg} \mathrm{kg}^{-1} \mathrm{dw}$, about an order of magnitude greater than the content of $\mathrm{Pb}$ in the Hi prepupae used to prepare the insect meal, equal to $0.059 \pm 0.007 \mathrm{mg} \mathrm{kg}^{-1} \mathrm{ww}$ $(12 \% \mathrm{M})$. With the increase in the percentage of $\mathrm{HI}$ meal in the experimental diets, a statistically significant decrease of $\mathrm{Pb}$ content was evidenced $(p<0.0001)$; in particular, Hi75 and Hi100 diets showed a Pb content significantly lower than the Hi50 diet, which in turn showed a significantly lower $\mathrm{Pb}$ content with respect to the Hi25 and Control diets. Referring to the EC limit [45] on undesirable substances in animal feed, the mean value of $\mathrm{Pb}$ content, $0.48 \pm 0.18 \mathrm{mg} \mathrm{kg}^{-1} \mathrm{ww}(12 \% \mathrm{M})$, was about ten-fold lower than the legal limit of $5 \mathrm{mg} \mathrm{kg}^{-1} \mathrm{ww}$ both for animal feed and fish feed.

$\mathrm{Hg}$ content varied from 0.032 to $0.037 \mathrm{mg} \mathrm{kg}^{-1} \mathrm{ww}(12 \% \mathrm{M})$ (Table 2), corresponding to a range from 0.036 to $0.042 \mathrm{mg} \mathrm{kg}^{-1} \mathrm{dw}$. These values are of the same order of magnitude as the $\mathrm{Hg}$ content in Hi prepupae used to prepare insect meal $\left(0.053 \pm 0.03 \mathrm{mg} \mathrm{kg}^{-1} \mathrm{ww}\right.$, $12 \% \mathrm{M})$. No statistically significant differences were evidenced between tested diets 
$(p>0.05)$. Referring to the EC limit [45] on undesirable substances in animal feed, the mean value of $\mathrm{Hg}$ content, $0.034 \pm 0.002 \mathrm{mg} \mathrm{kg}^{-1} \mathrm{ww}(12 \% \mathrm{M})$, was about six-fold lower than the legal limit of $0.2 \mathrm{mg} \mathrm{kg}^{-1} \mathrm{ww}$ reported for complete feed for fish.

Arsenic content varied from 0.11 to $0.21 \mathrm{mg} \mathrm{kg}^{-1} \mathrm{ww}(12 \% \mathrm{M})$ (Table 2), corresponding to a range from 0.13 to $0.24 \mathrm{mg} \mathrm{kg}^{-1} \mathrm{dw}$. The Control diet showed an Arsenic content about 2-fold higher than the As content in Hi meal $\left(0.109 \pm 0.003 \mathrm{mg} \mathrm{kg}^{-1} \mathrm{ww}, 12 \% \mathrm{M}\right)$. Consequently, with the increase in the percentage of Hi meal in the diets from $0 \%$ (CTRL) to $25 \%$ (Hi25) and to $50 \%$ (Hi50), a statistically significant decrease of As content was evidenced $(p<0.0001)$. No statistically significant differences were evidenced in As content among Hi50, Hi75, and Hi100 diets. Referring to the EC limit [45] on undesirable substances in animal feed, the mean value of As content, $0.14 \pm 0.04 \mathrm{mg} \mathrm{kg}^{-1} \mathrm{ww}(12 \% \mathrm{M})$, was about 70-fold lower than the legal limit of $10 \mathrm{mg} \mathrm{kg}^{-1} \mathrm{ww}$ reported for complete feed for fish.

$\mathrm{Ni}$ content varied from 0.11 to $1.72 \mathrm{mg} \mathrm{kg}^{-1} \mathrm{ww}(12 \% \mathrm{M})$ (Table 2), corresponding to a range from 0.12 to $1.95 \mathrm{mg} \mathrm{kg}^{-1} \mathrm{dw}$. The Ni content of the Control diet is greater than the content of $\mathrm{Ni}$ in the Hi prepupae used to prepare insect meal, $1.06 \pm 0.04 \mathrm{mg} \mathrm{kg}^{-1} \mathrm{ww}$ $(12 \% \mathrm{M})$. In parallel to the increase in the percentage of Hi meal in the diets, a statistically significant decrease of $\mathrm{Ni}$ content was evidenced $(p<0.0001)$, with a reduction of about 15 times from the Control diet to the Hi100 diet.

Table 2. PTEs content ( $\mathrm{mg} \mathrm{kg}^{-1} \mathrm{ww}$ ) in Hi meal and feed, referring to the EC limits [45] on undesirable substances in complete feed (maximum content relative to a feeding stuff with a moisture content of $12 \%)$.

\begin{tabular}{|c|c|c|c|c|c|}
\hline Diets & $\mathrm{Cd}$ & $\mathbf{P b}$ & $\mathrm{Hg}$ & As & $\mathrm{Ni}$ \\
\hline Legal Limit for Fish Feed & 1.0 & 5.0 & 0.2 & 10 & - \\
\hline Hi meal * & $0.20 \pm 0.02$ & $0.059 \pm 0.007$ & $0.053 \pm 0.003$ & $0.109 \pm 0.003$ & $1.06 \pm 0.04$ \\
\hline CTRL & $0.38 \pm 0.02^{b}$ & $0.63 \pm 0.04^{c}$ & $0.033 \pm 0.001^{\mathrm{a}}$ & $0.21 \pm 0.01^{c}$ & $1.72 \pm 0.04^{\mathrm{d}}$ \\
\hline Hi25 & $0.31 \pm 0.02^{\mathrm{a}}$ & $0.71 \pm 0.04^{\mathrm{c}}$ & $0.035 \pm 0.001^{\mathrm{a}}$ & $0.14 \pm 0.01^{b}$ & $1.04 \pm 0.11^{\mathrm{c}}$ \\
\hline $\mathrm{Hi} 50$ & $0.45 \pm 0.02^{c}$ & $0.42 \pm 0.02^{b}$ & $0.037 \pm 0.001^{\mathrm{a}}$ & $0.12 \pm 0.01^{\mathrm{a}}$ & $0.20 \pm 0.02^{b}$ \\
\hline $\mathrm{Hi} 75$ & $0.51 \pm 0.03^{c}$ & $0.34 \pm 0.02^{\mathrm{a}}$ & $0.032 \pm 0.001^{\mathrm{a}}$ & $0.12 \pm 0.01^{\mathrm{a}}$ & $0.21 \pm 0.03^{b}$ \\
\hline Hi100 & $0.46 \pm 0.04^{c}$ & $0.31 \pm 0.02{ }^{a}$ & $0.034 \pm 0.002^{\mathrm{a}}$ & $0.11 \pm 0.01^{a}$ & $0.11 \pm 0.01^{a}$ \\
\hline
\end{tabular}

Diets Hi25, Hi50, Hi75, and Hi100: increasing inclusion levels (25\%, 50\%, 75\%, and 100\% respectively) of full-fat Hermetia illucens prepupae in substitution of fish meal and fish oil referred to the Control diet (CTRL). * From Truzzi et al. [16]. Means within columns bearing different letters are significantly different $(p<0.05)$.

\subsection{Potentially Toxic Elements in Danio rerio}

PTEs content of zebrafish specimens (larvae, juvenile and adult) is reported in Figures 1-5 ( $\left.\mathrm{mg} \mathrm{kg}^{-1} \mathrm{dw}\right)$. Moreover, PTEs content in experimental diets is also reported in Figures $1-5\left(\mathrm{mg} \mathrm{kg}^{-1} \mathrm{dw}\right)$, for a visual comparison. Table 3 shows the bioaccumulation factor (BAF) for zebrafish in the investigated life stages, calculated on a dry-weight basis.

Table 3. Bioaccumulation factor (BAF) of PTEs in larval (L), juvenile (J), and adult (A) specimens of zebrafish, calculated on a dry-weight basis.

\begin{tabular}{|c|c|c|c|c|c|}
\hline Sample * & $\mathrm{Cd}$ & $\mathrm{Pb}$ & $\mathrm{Hg}$ & As & $\mathrm{Ni}$ \\
\hline $\mathrm{L}_{\mathrm{CTRL}}$ & $0.10 \pm 0.01$ & $0.23 \pm 0.2$ & $0.20 \pm 0.01$ & $2.0 \pm 0.2$ & $0.49 \pm 0.04$ \\
\hline $\mathrm{L}_{\mathrm{Hi} 25}$ & $0.16 \pm 0.01$ & $0.34 \pm 0.02$ & $0.31 \pm 0.02$ & $2.8 \pm 0.4$ & $0.9 \pm 0.1$ \\
\hline $\mathrm{L}_{\mathrm{Hi50}}$ & $0.09 \pm 0.01$ & $0.55 \pm 0.03$ & $0.24 \pm 0.01$ & $2.9 \pm 0.2$ & $2.3 \pm 0.3$ \\
\hline $\mathrm{L}_{\mathrm{Hi} 75}$ & $0.08 \pm 0.01$ & $0.87 \pm 0.04$ & $0.20 \pm 0.01$ & $3.4 \pm 0.1$ & $3.1 \pm 0.5$ \\
\hline $\mathrm{L}_{\mathrm{Hi} 100}$ & $0.11 \pm 0.01$ & $1.9 \pm 0.1$ & $0.15 \pm 0.01$ & $3.2 \pm 0.4$ & $27 \pm 3$ \\
\hline $\mathrm{J}_{\mathrm{CTRL}}$ & $0.7 \pm 0.1$ & $0.32 \pm 0.02$ & $2.2 \pm 0.2$ & $2.8 \pm 0.3$ & $2.2 \pm 0.1$ \\
\hline $\mathrm{J}_{\mathrm{Hi} 25}$ & $1.3 \pm 0.1$ & $0.47 \pm 0.03$ & $2.0 \pm 0.1$ & $2.4 \pm 0.3$ & $1.9 \pm 0.2$ \\
\hline $\mathrm{J}_{\mathrm{Hi} 50}$ & $0.7 \pm 0.1$ & $0.84 \pm 0.05$ & $1.8 \pm 0.2$ & $1.8 \pm 0.2$ & $5.2 \pm 0.8$ \\
\hline $\mathrm{J}_{\mathrm{Hi} 75}$ & $1.3 \pm 0.1$ & $0.98 \pm 0.07$ & $2.1 \pm 0.3$ & $0.8 \pm 0.1$ & $10 \pm 2$ \\
\hline $\mathrm{J}_{\mathrm{Hi} 100}$ & $1.5 \pm 0.1$ & $3.4 \pm 0.1$ & $2.1 \pm 0.2$ & $0.9 \pm 0.2$ & $39 \pm 3$ \\
\hline$A_{C T R L}$ & $0.8 \pm 0.1$ & $0.32 \pm 0.05$ & $2.8 \pm 0.2$ & $3.7 \pm 0.6$ & $3.5 \pm 0.6$ \\
\hline $\mathrm{A}_{\mathrm{Hi} 25}$ & $1.3 \pm 0.2$ & $0.65 \pm 0.14$ & $2.7 \pm 0.2$ & $2.8 \pm 0.6$ & $2.3 \pm 0.4$ \\
\hline $\mathrm{A}_{\mathrm{Hi} 50}$ & $0.8 \pm 0.1$ & $0.91 \pm 0.14$ & $2.4 \pm 0.2$ & $2.7 \pm 0.6$ & $7.4 \pm 2.0$ \\
\hline
\end{tabular}


Table 3. Cont.

\begin{tabular}{cccccc}
\hline Sample $^{*}$ & $\mathrm{Cd}$ & $\mathrm{Pb}$ & $\mathrm{Hg}$ & $\mathrm{As}$ & $\mathrm{Ni}$ \\
\hline $\mathrm{A}_{\mathrm{Hi} 75}$ & $\mathbf{1 . 3} \pm \mathbf{0 . 1}$ & $\mathbf{1 . 2} \pm \mathbf{0 . 1}$ & $\mathbf{2 . 7} \pm \mathbf{0 . 2}$ & $\mathbf{1 . 4} \pm \mathbf{0 . 3}$ & $\mathbf{1 1} \pm \mathbf{2}$ \\
$\mathrm{A}_{\text {Hi100 }}$ & $\mathbf{1 . 5} \pm \mathbf{0 . 2}$ & $3.7 \pm \mathbf{0 . 4}$ & $\mathbf{2 . 6} \pm \mathbf{0 . 3}$ & $\mathbf{1 . 4} \pm \mathbf{0 . 2}$ & $\mathbf{4 1} \pm \mathbf{6}$ \\
\hline
\end{tabular}

${ }^{*}$ Fish fed diet including $0 \%\left(\mathrm{X}_{\mathrm{CTRL}}\right), 25 \%,\left(\mathrm{X}_{\mathrm{Hi} 25}\right), 50 \%\left(\mathrm{X}_{\mathrm{Hi} 50}\right), 75 \%\left(\mathrm{X}_{\mathrm{Hi} 5}\right)$, and $100 \%\left(\mathrm{X}_{\mathrm{Hi} 100}\right)$ insect meal. Values highlighted in bold are higher than 1 .

\subsubsection{Cadmium}

Zebrafish larvae showed Cd content from 0.044 to $0.054 \mathrm{mg} \mathrm{kg}^{-1} \mathrm{dw}$ (from 0.0068 to $0.0082 \mathrm{mg} \mathrm{kg}^{-1} \mathrm{ww}$ ), and no significant differences were evidenced among groups $(p>0.05)$ (Figure 1). All groups of larvae had a statistically significant lower Cd content than juvenile and adult specimens $(p<0.001)$. Juvenile and adult specimens fed with the same diet showed a similar Cd content, which ranged from 0.32 to $0.73 \mathrm{mg} \mathrm{kg}^{-1} \mathrm{dw}$ (0.08-0.16 mg kg $\left.{ }^{-1} \mathrm{ww}\right)$ and from 0.35 to $0.79 \mathrm{mg} \mathrm{kg}^{-1} \mathrm{dw}\left(0.11-0.25 \mathrm{mg} \mathrm{kg}^{-1} \mathrm{ww}\right)$, respectively. Moreover, $\mathrm{Cd}$ concentration in juvenile and adult zebrafish fed with Hi75 and Hi100 diets increased significantly compared to specimens fed with the diets including lower percentages of Hi meal $(p<0.01)$. The BAF for larvae is about 0.1 and in juvenile and in adult specimens is about 1 (Table 3), apart from specimens fed with Hi75 and Hi100 diet, which showed a BAF of just over 1.

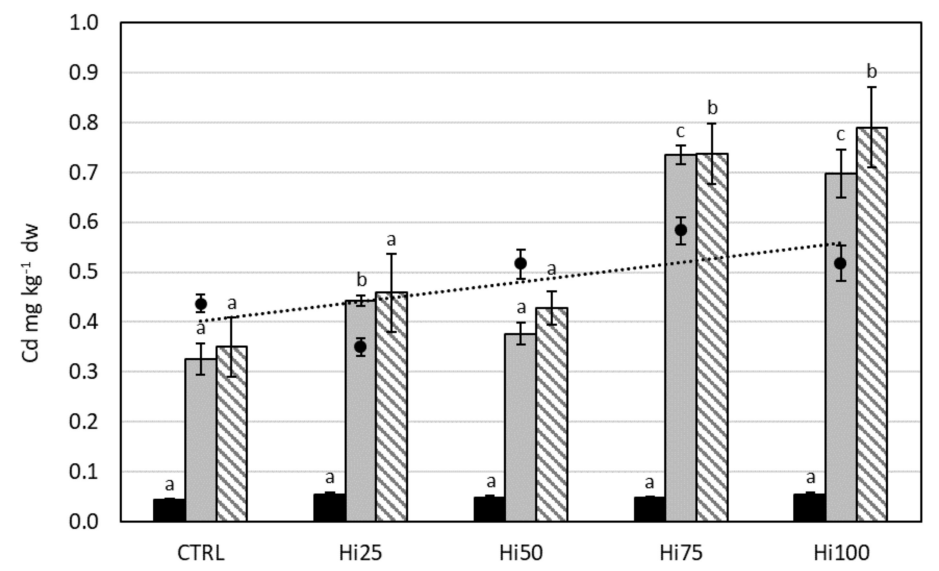

Figure 1. Cadmium content ( $\mathrm{mg} \mathrm{kg}^{-1} \mathrm{dw}$ ) in diets (dark spot, dashed trend line) and in larvae (black bars), juveniles (gray bars), and adults (striped bars) of Danio rerio fed with experimental diets: CTRL, control; Hi25, Hi50, Hi75, and Hi100, diets enriched with 25, 50, 75, and 100\% of Hi full-fat prepupae, respectively. The values are presented as mean \pm standard deviation $(n=3)$. Different letters indicate statistically significant differences between specimens of the same life stage $(p<0.05)$.

\subsubsection{Lead}

Within the same life stage, the $\mathrm{Pb}$ content in zebrafish specimens increased significantly as the percentage of insect inclusion in the diet increased $(p<0.0001)$ (Figure 2): from 0.16 (CTRL) to 0.66 (Hi100) $\mathrm{mg} \mathrm{kg}^{-1} \mathrm{dw}$ in larvae, from 0.23 (CTRL) to 1.19 (Hi100) $\mathrm{mg} \mathrm{kg}^{-1} \mathrm{dw}$ in juveniles, and from 0.23 (CTRL) to 1.30 (Hi100) $\mathrm{mg} \mathrm{kg}^{-1} \mathrm{dw}$ in adults. By consequence, for each life stage, zebrafish specimens fed with insect-based diets showed a significantly higher $\mathrm{Pb}$ content than specimens fed with the control diet. In addition, fish fed with the Hi100 diet showed a significantly higher $\mathrm{Pb}$ content than fish of the same life stage fed with the Hi25, Hi50, and Hi75 diets, which generally showed no statistically significant differences between them. Comparing the different life stages, we observed how, in the fishes fed with the same diet, the content of lead increased significantly, passing from the larvae to the juveniles $(p<0.05)$ and from the juveniles to the adults $(p<0.05)$, except in the case of juveniles and adults fed with the Control diet, which did not show a statistically significant difference between them. In general, for each life stage, BAF increased as the 
percentage of insect meal included in the diet increased, reaching a value $>1$ in specimens fed with the Hi100 diet and for adults fed with the Hi75 diet (Table 3).

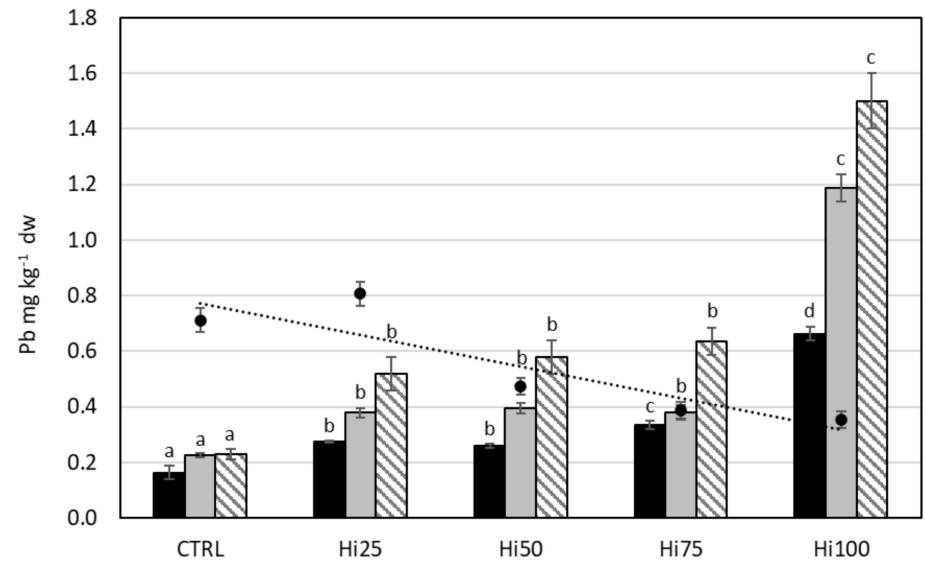

Figure 2. Lead content ( $\mathrm{mg} \mathrm{kg}^{-1} \mathrm{dw}$ ) in diets (dark spot, dashed trend line) and in larvae (black bars), juveniles (gray bars), and adults (striped bars) fed with experimental diets: CTRL, control; Hi25, $\mathrm{Hi} 50$, Hi75, and Hi100, diets enriched with 25, 50, 75, and 100\% of Hi full-fat prepupae, respectively. The values are presented as mean \pm standard deviation $(n=3)$. Different letters indicate statistically significant differences between specimens of the same life stage $(p<0.05)$.

\subsubsection{Mercury}

Figure 3 shows the content of mercury in the Danio rerio specimens in the various phases of the life cycle (larvae, juveniles, and adults). Larvae showed a statistically significant reduction of $\mathrm{Hg}$ content with increasing percentage of the inclusion of Hi meal in the diet $(p<0.0001)$, passing from $12.4 \mu \mathrm{g} \mathrm{kg}^{-1} \mathrm{dw}$ for larvae fed with the Hi25 diet to $5.5 \mu \mathrm{g} \mathrm{kg}^{-1} \mathrm{dw}$ for larvae fed with the Hi100 diet. Juveniles showed a Hg content of $\sim 80 \mu \mathrm{g} \mathrm{kg}^{-1} \mathrm{dw}$, and no statistically significant differences between specimens bred with different diets $(p>0.05)$ were shown. The same result has been obtained for adult specimens, since all groups showed a $\mathrm{Hg}$ content of $\sim 100 \mu \mathrm{g} \mathrm{kg}{ }^{-1} \mathrm{dw}$. Comparing the different life stages between fishes fed with the same diet, the concentration of $\mathrm{Hg}$ increased significantly $(p<0.01)$ passing from the larvae to the juveniles and, finally, to the adult specimens. BAF values (0.1-0.3 for larvae specimens, $\sim 2$ for juveniles, and $\sim 2.7$ for adults) highlighted a different bioaccumulation capacity among the life stages considered.

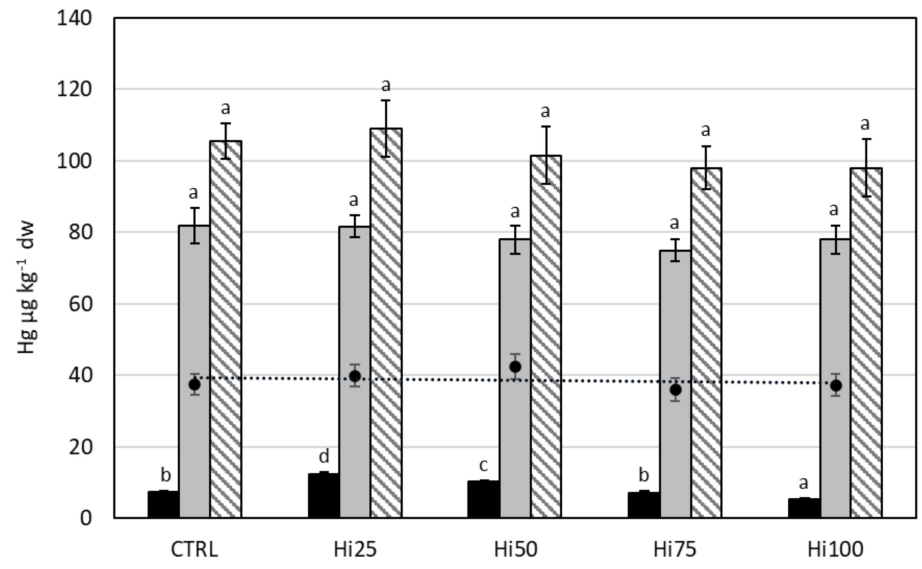

Figure 3. Mercury content ( $\mu \mathrm{g} \mathrm{kg}^{-1} \mathrm{dw}$ ) in diets (dark spot, dashed trend line) and in larvae (black bars), juveniles (gray bars), and adults (striped bars) of Danio rerio fed with experimental diets: CTRL, control; Hi25, Hi50, Hi75, and Hi100, diets enriched with 25, 50, 75, and 100\% of Hi full-fat prepupae, respectively. The values are presented as mean \pm standard deviation $(n=3)$. Different letters indicate statistically significant differences between specimens of the same life stage $(p<0.05)$. 


\subsubsection{Arsenic}

For each life stage, all groups of specimens fed with insect-based diets showed a statistically lower As content than specimens fed with the Control diet $(p<0.0001)$ (Figure 4). Moreover, zebrafish larvae fed with the Hi100 diet showed a significant decrease $(p<0.05)$ in As content $\left(0.39 \mathrm{mg} \mathrm{kg}^{-1} \mathrm{dw}\right)$ compared to larvae fed with the Hi25 and Hi75 diets (0.44 and $0.45 \mathrm{mg} \mathrm{kg}^{-1} \mathrm{dw}$, respectively) (Figure 4), but the decrease is much less pronounced than the decrease shown in juveniles and adults. In particular, as the percentage of insect inclusion in the diet increases, the As content decreased significantly $(p<0.0001)$ passing: (i) in juveniles, from $0.38 \mathrm{mg} \mathrm{kg}^{-1} \mathrm{dw}$ in specimens fed with Hi25 diet, to $0.12 \mathrm{mg} \mathrm{kg}^{-1} \mathrm{dw}$ in fish fed with the Hi100 diet; (ii) in adult, from $0.44 \mathrm{mg} \mathrm{kg}^{-1} \mathrm{dw}$ in specimens fed with Hi25 diet to $0.18 \mathrm{mg} \mathrm{kg}^{-1} \mathrm{dw}$ in fish fed with the Hi100 diet. As for a comparison among life stages, in fish fed with the control diet, the content of As increased significantly from larvae to juveniles and, finally, to adults $(p<0.05)$. In specimens fed diets containing Hi meal, in contrast, larvae had an equal or higher As content than juveniles and adults. The BAF for arsenic is generally $>1$ for all groups of considered life stages (larvae, 2-3.4; juveniles, 1.8-2.8; adults, 1.4-3.7), except for juveniles fed with Hi75 (0.8) and Hi100 (0.9) diets.

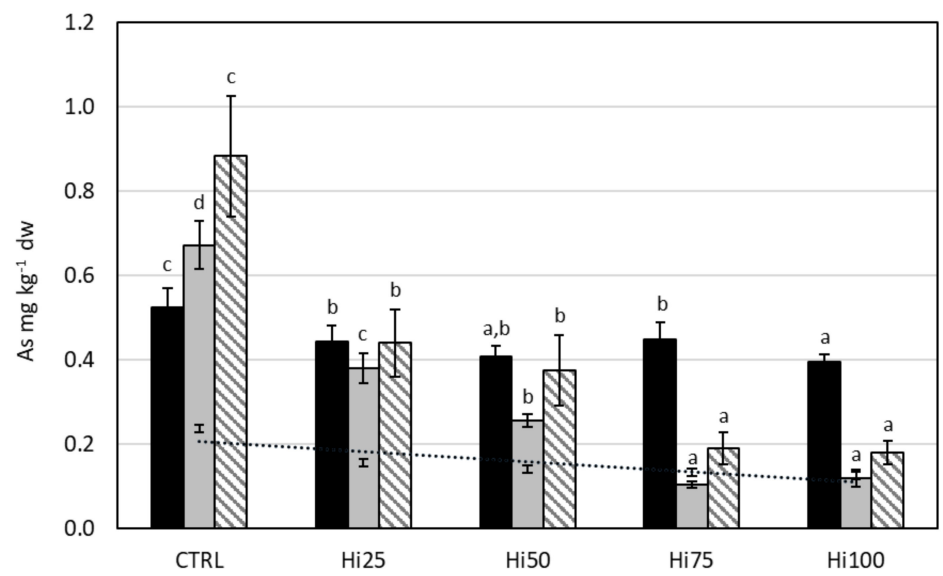

Figure 4. Arsenic content $\left(\mathrm{mg} \mathrm{kg}^{-1} \mathrm{dw}\right.$ ) in diets (dark spot, dashed trend line) and in larvae (black bars), juveniles (gray bars), and adults (striped bars) of Danio rerio fed with experimental diets: CTRL, control; Hi25, Hi50, Hi75, and Hi100, diets enriched with 25, 50, 75, and 100\% of Hi full-fat prepupae, respectively. The values are presented as mean \pm standard deviation $(n=3)$. Different letters indicate statistically significant differences between specimens of the same life stage $(p<0.05)$.

\subsubsection{Nickel}

The trend of Ni content in zebrafish as a function of the administered diets was different from other studied PTEs and was similar for the different life stages (Figure 5). In particular, with the increase in the percentage of Hi meal in the diet, there was a significant decrease from specimens fed with the control diet to those fed with the insect-based diets Hi25 and Hi50. Then, a further increase in the percentage of Hi meal in the diet from $75 \%$ to $100 \%$ led to a statistically significant increase of Ni content in zebrafish specimens ( $p<0.0001$ for larvae, juveniles, and adults). The significantly lowest Ni content has been found in individuals fed the Hi50 diet for all considered life stages. As for the comparison among life stages, we observed how, in specimens fed with the same diet, the content of $\mathrm{Ni}$ increased significantly passing from larvae to juveniles $(p<0.05)$ for all considered diets and from juveniles to adults $(p<0.05)$ for specimens fed with Control, Hi25, and Hi50 diets. Concerning the BAF, all specimens considered showed a value $>1$, except for larvae fed with the Control and Hi25 diets. For all life stages, we observed an exponential growth of $\mathrm{BAF}$ with increasing percentage of the inclusion of $\mathrm{Hi}$ meal in the diet, from specimens fed the Hi25 diet to specimens fed the Hi100 diet. 


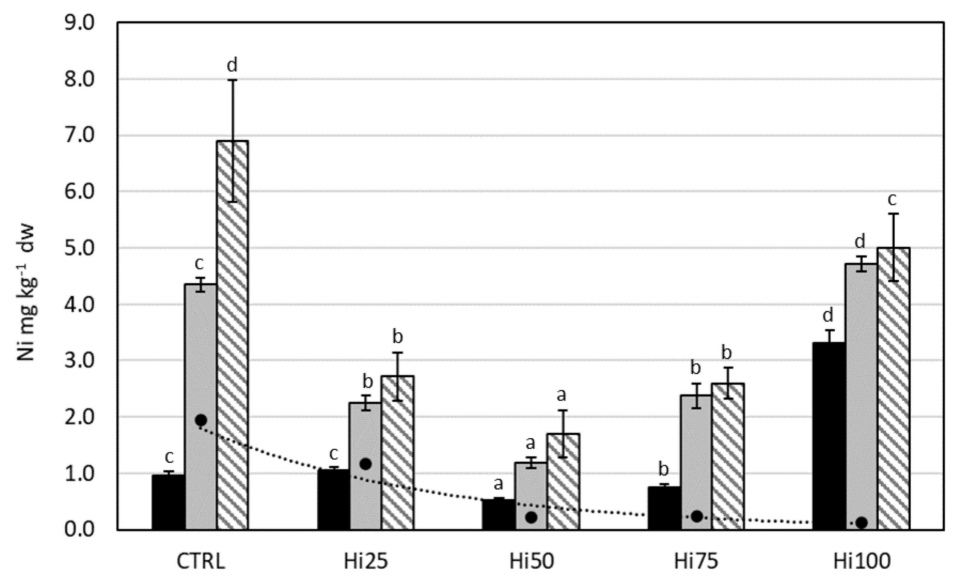

Figure 5. Nikel content (mg kg${ }^{-1} \mathrm{dw}$ ) in diets (dark spot, dashed trend line) and in larvae (black bars), juveniles (gray bars), and adults (striped bars) of Danio rerio fed with experimental diets: CTRL, control; Hi25, Hi50, Hi75, and Hi100, diets enriched with 25, 50, 75, and 100\% of Hi full-fat prepupae, respectively. The values are presented as mean \pm standard deviation $(n=3)$. Different letters indicate statistically significant differences between specimens of the same life stage $(p<0.05)$.

\section{Discussion}

\subsection{Potentially Toxic Elements in the Experimental Diets}

Several studies have confirmed that food can be a major source of trace metals in fish $[32,33,78,79]$, and fish feed is the major food for farmed fish. Therefore, it is important to find substitutes of FM that can reduce the content of these toxic elements in the diet. In turn, the content of PTEs in insects depends on the rearing substrate used for their growth [15-17]. Hi prepupae used in this study were growth with a substrate based on by-products obtained from roasting coffee (coffee silverskin) added with $10 \%(w / w)$ of Schizochytrium sp. [58]: the study demonstrated that $\mathrm{Hi}$ prepupae accumulate $\mathrm{Cd}, \mathrm{Pb}$, and $\mathrm{Hg}$ in their body; however, the content of PTEs was lower than the legal limit for feed (data reported in Table 3).

The results of this study concerning the content of PTEs in the diets administered to Danio rerio allow us to make the following considerations.

$\mathrm{Cd}$ and $\mathrm{Hg}$ concentrations found in experimental diets (mean, $0.47 \pm 0.09$, and $0.038 \pm 0.002 \mathrm{mg} \mathrm{kg}^{-1} \mathrm{ww}$, respectively) of this study are of the same order of magnitude of their content in complete Atlantic salmon feed used from 2008 to 2017, 0.2-0.3 $\mathrm{mg} \mathrm{kg}^{-1} \mathrm{ww}$ for $\mathrm{Cd}$ and $0.050 \pm 0.0070 \mathrm{mg} \mathrm{kg}^{-1} \mathrm{ww}$ for $\mathrm{Hg}$ [10] or in complete feed used for Seriola dumerili (0.41-0.60 $\mathrm{mg} \mathrm{kg}^{-1} \mathrm{ww}$ for Cd), wherein FM has been replaced with alternative protein sources, such as corn gluten meal, krill meal, and meat and bone meal [80]. The concentration of arsenic (mean, $0.16 \pm 0.05 \mathrm{mg} \mathrm{kg}^{-1} \mathrm{ww}$ ) was one order of magnitude lower than the complete Atlantic salmon feed in 2008-2017, $2.6 \mathrm{mg} \mathrm{kg}^{-1} \mathrm{ww}$ [10] and in complete feed for Seriola dumerili, 1.86-3.15 $\mathrm{mg} \mathrm{kg}^{-1} \mathrm{ww}$ [80]. The $\mathrm{Pb}$ content of the experimental diets (mean, $0.54 \pm 0.2 \mathrm{mg} \mathrm{kg}^{-1} \mathrm{ww}$ ) was one order of magnitude greater with respect to complete feed for Atlantic salmon from 2008 to 2017, $0.05-0.07 \mathrm{mg} \mathrm{kg}^{-1} \mathrm{ww}$ [10]. The inclusion of Hi meal in substitution of FM and FO modified the content of some PTEs in the experimental diets. In particular, the increase of the inclusion level of Hi prepupae meal in the diets in substitution of FM resulted in a statistically significant ( $p=0.0022$ ) decrease of $\mathrm{Pb}, \mathrm{As}$, and $\mathrm{Ni}$, whereas $\mathrm{Hg}$ content did not show significant changes. Moreover, a statistically significant decrease of Cd content was evidenced ( $p=0.0022)$ in Hi25 with respect to the Control diet, whereas the further inclusion of Hi meal in substitution of FM led to a statistically significant increase of Cd content $(p=0.0022)$ in Hi50, Hi75, and Hi100 diets with respect to the Control diet and the Hi25 diet. These results are in line with the fact that, compared to FM and FO, Hi meal showed a similar $\mathrm{Cd}$ and $\mathrm{Hg}$ content, and a lower $\mathrm{Pb}, \mathrm{As}$, and $\mathrm{Ni}$ content. In consequence, the substitution of FM and FO with Hi meal determined a change in PTEs content in feed. 
These results agreed with literature data. Biancarosa et al. [57] demonstrated that the increased dietary inclusion of Hi meal in substitution of FM and FO in feed provided to Atlantic salmon Salmo salar led to an increase in the Cd content, whereas Hg did not show statistically significant differences between the tested feed. For $\mathrm{Pb}$, contrary to what we found, they showed a slight increase with the increase of Hi meal in the diet. Monge-Ortiz et al. [80] found that FM substitution with alternative protein sources led to a decrease of As content in feed, and $\mathrm{Hg}$ did not show significant changes, as observed in the experimental diets of this study. However, $\mathrm{Cd}$ content showed a decrease passing from a diet based on FM to a diet wherein FM were replaced with corn gluten meal, krill meal, and meat and bone meal. The discrepancy of the results is probably tied to the different kind of fish feed used for the fish farm.

All investigated PTEs showed a lower content than legal limits intended for feed [45] (except for the $\mathrm{Ni}$, for which no legal limit is reported in the regulation in force); therefore, there is no chemical risk associated with the presence of these elements. This result made it possible to apply the same type of experimental diet to a species of edible fish, the sturgeon [81], as part of the NUTRIFISH Project. In the immediate future, this finding opens the possibility of exploiting an eco-sustainable resource, such as insects, for the breeding of edible species in aquaculture, reducing the exploitation of fish species to produce FM and FO.

\subsection{Potentially Toxic Elements in Danio rerio}

The PTEs content in fish is a function of their concentration in the environment and in the diet and of the exposure period [82]. PTEs levels in the diets (min-max, $\mathrm{mg} \mathrm{kg}^{-1} \mathrm{dw}$ : $\mathrm{Cd}$ 0.35-0.58, Pb 0.35-0.81, As 0.13-0.24, Ni 0.12-1.95, Hg 0.036-0.042) showed a content much higher with respect to PTEs concentration in tank water (Table 3): about 5 orders of magnitude for $\mathrm{Cd}$ and $\mathrm{Pb}, 4$ for $\mathrm{As}$ and $\mathrm{Hg}$, and 2-3 for $\mathrm{Ni}$. These results suggested that the PTEs content in water is negligible; therefore, we can assume that the PTEs content in zebrafish specimens was influenced almost exclusively by the PTEs content in the diet.

\subsubsection{Cadmium}

The mean value of $\mathrm{Cd}$ content for the different life stages was $0.050 \pm 0.04,0.5 \pm 0.2$, $0.5 \pm 0.2 \mathrm{mg} \mathrm{kg}^{-1} \mathrm{dw}$ for larvae, juvenile, and adults, respectively. These results were consistent with literature data (Table 4) for zebrafish specimens subjected to experiments in aquaria [32,33,69-71,75], within the limits of the experimental error. In particular, $\mathrm{Cd}$ content in larvae $\left(0.007 \mathrm{mg} \mathrm{kg}^{-1} \mathrm{ww}\right)$ was similar to Cd content in larvae from Boyle [32], $\sim 0.02 \mathrm{mg} \mathrm{kg}^{-1} \mathrm{ww}$; adult specimens showed a Cd content $\left(0.35-0.79 \mathrm{mg} \mathrm{kg}^{-1} \mathrm{dw}\right.$, 0.11-0.25 $\mathrm{mg} \mathrm{kg}^{-1} \mathrm{ww}$ ) similar to the Cd content in adult zebrafish from Lacave et al. [69], $1.5 \mathrm{mg} \mathrm{kg}^{-1} \mathrm{dw}$, from Gonzalez et al. [75], $0.200 \pm 0.03 \mathrm{mg} \mathrm{kg}^{-1} \mathrm{dw}$, and from Zhan et al. [83], $\sim 0.75 \mathrm{mg} \mathrm{kg}^{-1} \mathrm{ww}$. The obtained results showed that the concentration of this metal increases both with the growth of zebrafish (and then with the exposure time) and with the increase of the percentage of insect meal present in the feed. In fact, juveniles and adults have a content of $\mathrm{Cd}$ about 10 times greater than larvae; in addition, juveniles and adults fed on the highest insect meal inclusion diets (Hi75 and Hi100) showed a statistically higher $\mathrm{Cd}$ content than other groups. In literature increasing evidence has shown that several factors influence the accumulation of $\mathrm{Cd}$ in fish tissues, such as the concentration of this metal in the environment or in the diet and the exposure time $[68,71,84,85]$. The BAF for larvae is about 0.1 , and in juvenile and adult specimens, it is about 1 , emphasizing how $\mathrm{Cd}$ accumulation depends also on the life stage. A bioaccumulation factor $\leq 1$ indicates no bioaccumulation; therefore, the $\mathrm{Cd}$ reaches its highest concentration in the juveniles and then remains constant in the adult specimens, without bioaccumulation. Previous literature demonstrated that $\mathrm{Cd}$ is accumulated by different organs due to different doses of $\mathrm{Cd}^{2+}$ treatment and different exposure times [82,86]: in these cases, differently from our study, higher levels of $\mathrm{Cd}$ were added in the tank water. In addition, aquatic $\mathrm{Cd}$ binds generally more efficiently in fish than dietary $\mathrm{Cd}$ [87], and we demonstrated a very low Cd content 
in the aquatic media of the zebrafish farm (Table 1). Our data were consistent with data reported by Rehwoldt and Karimian-Teherani [88], which showed an increase in Cd concentration in the zebrafish exposed to $10 \mathrm{ppm}$ of $\mathrm{Cd}$ added in feed, related to the exposure time: $\mathrm{Cd}$ content reached a plateau of about $5 \mathrm{mg} \mathrm{kg}^{-1} \mathrm{dw}$ after 2-3 months of exposure. In our study, the juvenile specimens of 2 months had the same $\mathrm{Cd}$ content of the adult specimens, and an equilibrium was reached between the rate of retention and the rate of excretion. It is known that, in fish, low levels of Cd induce metallothionein formation [89,90]; thus the low accumulation of the metal in the fish tissues is possibly due to the binding of the metal in the liver with metallothionein molecules with its subsequent depuration from the organs. We can therefore conclude that the $\mathrm{Cd}$ present in the feeding substrate enter the body of zebrafish in different life stages, but it is excreted without bioaccumulation.

\subsubsection{Lead}

The mean value of $\mathrm{Pb}$ content for the different life stages was $0.3 \pm 0.2,0.5 \pm 0.2$, $0.6 \pm 0.4 \mathrm{mg} \mathrm{kg}^{-1} \mathrm{dw}$ for larvae, juvenile, and adults, respectively. It is not possible to compare our results with literature data, since usually zebrafish specimens have been exposed to elevated concentrations of $\mathrm{Pb}$ in the water tank for toxicological studies, and $\mathrm{Pb}$ content was measured in different tissues [68,83]. Although the content of $\mathrm{Pb}$ in the experimental diets tends to decrease as the percentage of Hi meal increases, zebrafish specimens of all life stages showed an increase in $\mathrm{Pb}$ concentration, passing from the Control diet to the Hi100 diet. These results could appear to contrast with studies conducted on zebrafish exposed to contaminated river water [68] or to high $\mathrm{Pb}$ concentration in tank water [83], which showed that lead tends to bioaccumulate in the body, especially in gills and liver, as the external concentration of $\mathrm{Pb}$ increases, reaching a concentration of $0.2-38 \mathrm{mg} \mathrm{kg}^{-1} \mathrm{ww}$ in gills and liver for exposure to $\sim 16 \mathrm{mg} \cdot \mathrm{L}^{-1}$ [68], or of about $2 \mathrm{mg} \mathrm{kg}^{-1} \mathrm{ww}$ in the carcass for exposure to $1 \mathrm{ppm}$ [83]. But it is known that $\mathrm{Pb}$ accumulation depends on several factors, including developmental stage, water quality, $\mathrm{Pb}$ concentration, and variability within and among populations and/or species [30,91]. Moreover, aquatic organisms take up lead from both the surrounding water and the diet, but it was demonstrated that the effects of dietary exposure to lead are relatively minor [92]. From the results of this study, we can hypothesize that the $\mathrm{Pb}$ present in Hi meal, although it is present in much lower concentrations than in the Control diet, is present in a more bioavailable and more easily assimilated form by zebrafish specimens in the various life stages considered. This hypothesis is supported by the value of the bioaccumulation factor found in zebrafish specimens: within each life stage, the BAF increases as the percentage of the inclusion of insect meal in the diet increases, highlighting the ability of fish to bioaccumulate $\mathrm{Pb}$ only in animals fed with diets containing the highest percentages of insect meal (Hi100), for larvae, juvenile, and adults (BAF $1.9 \pm 0.1,3.4 \pm 0.1,3.7 \pm 0.4$ respectively). These results agree with literature studies, which demonstrated that lead has little capacity to accumulate in fish muscle [14,93,94], while liver, kidney, and scales are the main sites for $\mathrm{Pb}$ accumulation [90,95], and similarly for zebrafish $[68,83]$. In addition, within the same diet administered, there is an increase in the content of $\mathrm{Pb}$ passing from larvae to juveniles and to adult specimens. The ability of zebrafish to uptake $\mathrm{Pb}$ could therefore depend both on the bioavailability of $\mathrm{Pb}$ present in the diet and on the life stage of the animal itself.

\subsubsection{Mercury}

The mean value of $\mathrm{Hg}$ content for the different life stages was $0.009 \pm 0.003$, $0.079 \pm 0.003,0.102 \pm 0.005 \mathrm{mg} \mathrm{kg}^{-1} \mathrm{dw}$ for larvae, juvenile, and adults, respectively. These results, within the limits of the experimental error, were consistent with literature data (Table 4), recorded in adult specimens of zebrafish, wherein $\mathrm{Hg}$ content was next to $0 \mathrm{mg} \mathrm{kg}^{-1} \mathrm{dw}$ [96]. It is known that the $\mathrm{Hg}$ content in fish depends on many factors, such as the presence in the environment [11] and in the diet [70] and the trophic level of the species $[29,97,98]$. Moreover, $\mathrm{Hg}$ distribution in fish depends on the life stage and on the $\mathrm{Hg}^{\prime}$ s affinity for different tissues. In zebrafish larvae, $\mathrm{Hg}$ is highly localized in the rapidly 
dividing lens epithelium, with lower levels going to brain, optic nerve, and various other organs [99], whereas adult zebrafish specimens fed with Hg-enriched diets accumulate the metal in muscle, liver, and brain, dependent on the $\mathrm{Hg}$ content in the diet and on the exposure time $[68,70,100]$.

In this study, larvae showed a significant reduction in $\mathrm{Hg}$ content as the percentage of Hi meal inclusion in the diet increases, thus decreasing from Hi25-fed to Hi100-fed individuals $(p<0.01)$. For both juvenile and adult specimens, the $\mathrm{Hg}$ content did not differ significantly between groups $(p>0.05)$. Zarantoniello et al. [78] demonstrated that higher inclusion levels of Hi meal in the diets (i.e., Hi75 and Hi100) affect larval liver histology of zebrafish and induce a general increase in lipid accumulation, unlike juveniles, who showed a decrease in total lipid content in specimens fed with the Hi75 and Hi100 diets with respect to the other experimental groups of the same life stages [101], and unlike adults, who showed a similar lipid content among groups (data not published). Several studies demonstrated a negative correlation between lipid content and $\mathrm{Hg}$ accumulation in fish [41,102]. Moreover, high inclusion levels of Hi meal in the diet lead to an alteration of molecular markers related to the appetite stimulus [78]. These physiological alterations could contribute to change the accumulation capacity of larvae towards mercury.

The Hg content increased as a function of the growth of the fish being studied: from larvae to juveniles and from juveniles to adults $(p<0.0001)$, reaching in adults a concentration of $\mathrm{Hg}$ about 10 times higher with respect to larvae. These results confirm the dependence of $\mathrm{Hg}$ content in fish on the exposure time, demonstrated by Gonzalez et al. [96]: zebrafish fed with $5 \mu \mathrm{g}$ of $\mathrm{Hg} \mathrm{g}^{-1} \mathrm{dw}$ contaminated food showed an increase in $\mathrm{Hg}$ content in muscle from day $7\left(\sim 3 \mathrm{mg} \mathrm{kg}^{-1} \mathrm{dw}\right)$ to day $63\left(\sim 15 \mathrm{mg} \mathrm{kg}^{-1} \mathrm{dw}\right)$ [72]. Larvae, which showed a statistically significant lower $\mathrm{Hg}$ content with respect to juveniles and adults, were not able to bioaccumulate $\mathrm{Hg}$ (BAF equal to about 0.2). Increasing the exposure time, $\mathrm{Hg}$ content in zebrafish specimens increased, then juveniles (BAF about 2) and even more adults (BAF about 2.7) bioaccumulated this metal. This data confirmed the bioaccumulation capacity of $\mathrm{Hg}$ in living organisms, as reported in the literature $[29,30,98]$.

\subsubsection{Arsenic}

The mean value of As content for the different life stages was $0.43 \pm 0.03,0.3 \pm 0.2$, $0.4 \pm 0.3 \mathrm{mg} \mathrm{kg}^{-1} \mathrm{dw}$ for larvae, juveniles, and adults, respectively. These results are consistent with literature data (Table 4) for adult zebrafish specimens, within the limits of the experimental error. In particular, adult specimens showed a content of As $\left(0.18-0.88 \mathrm{mg} \mathrm{kg}^{-1} \mathrm{dw}\right)$ similar to As content in adult zebrafish from Wang et al. [76], $0.94 \pm 0.08 \mathrm{mg} \mathrm{kg}^{-1} \mathrm{dw}$, and from Boyle et al. [33], 0.27-0.39 $\mathrm{mg} \mathrm{kg}^{-1} \mathrm{dw}$. Larvae exposed to $5 \mathrm{ppm}$ of As in a water tank showed As content about ten-fold higher $\left(0.4-0.5 \mathrm{mg} \mathrm{kg}^{-1} \mathrm{ww}\right)$ than larvae from this study [73].

For arsenic, results showed that the increase of the inclusion level of Hi prepupae meal in the diets, which corresponds to a decrease in As in feed, is accompanied by a reduction in the content of this toxic element in zebrafish, especially in juvenile and in adult specimens, and less markedly in larvae. The higher (or similar) content of As in larvae fed with $\mathrm{Hi}$ meal-based diets with respect to juveniles and adults could be explained by the lower larval metabolism, which slows down detoxification processes (such as methylation capacity) and the excretion of toxic substances [103]. Our results demonstrated a statistically significant linear positive relationship between As content in the diets and As content in the different zebrafish life stages: larvae $(p=0.0272, \mathrm{r}=0.9193)$, juvenile $(p=0.0090, \mathrm{r}=0.9616)$, and adult $(p=0.0036, \mathrm{r}=0.9792)$; therefore, we can deduce that As content in zebrafish is influenced by the level of As in the diet. This statement is supported by literature data: some authors demonstrated that dietary uptake could be the primary route for As bioaccumulation in fish [104,105], and a correlation between As content in the diet and As content in fish tissues has been already demonstrated in Danio rerio [106,107].

From the analysis of the BAF for As (2.0-3.4 for larvae; 0.9-2.8 for juvenile; 1.4-3.7 for adult), an ability was observed in zebrafish to bioaccumulate such metalloids, as demon- 
strated in the literature $[33,68,73]$. In particular, adult zebrafish exposed to contaminated river waters in an aquarium under static conditions for 7 consecutive days showed a BAF of 0.45 in gills and of 2.26 in liver [68]. Boyle [33] demonstrated the accumulation of As in adult zebrafish fed with the polychaete Nereis diversicolor collected from a metal-impacted estuary. Several studies demonstrated the ability of other fish species to accumulate As, such as striped snakehead (Channa striata) [108], juvenile rockfish (Sebastes schlegelii) [109], Tilapia (Oreochromis spp) [110], or brown trout (Salmo trutta) [111]. Bioaccumulation already occurs in the larval stage as the arsenic is absorbed through aquaglyceroporins (membrane proteins similar to mammalian aquaporins) that develop in the early stages of the life of the fish, so much so as to determine concentrations in larvae equal to those in the muscles of adults, as demonstrated by Hamdi et al. [73]. In that study, after a short-term exposure (2-6 days post fertilization for larvae, $96 \mathrm{~h}$ for adult) to $5 \mathrm{ppm}$ sodium arsenite, an As concentration of about $0.5 \mathrm{mg} \mathrm{kg}^{-1} \mathrm{ww}$ was recorded in larvae and in the muscle of adult specimens.

Arsenic is an element of concern for feed and food safety. Being naturally present in pelagic fish, it is transferred to marine feed ingredients, i.e., FM and FO, which are the major sources of arsenic in aquafeeds [14]. Due to the influence of the diet on As content in fish, the substitution of FM with an insect-based diet has the advantage of reducing the level of this metalloid in fish tissues.

\subsubsection{Nickel}

The mean value of $\mathrm{Ni}$ content for the different life stages was $1.3 \pm 0.03,3 \pm 1$, $4 \pm 2 \mathrm{mg} \mathrm{kg}^{-1} \mathrm{dw}$ for larvae, juveniles, and adults, respectively. These results were consistent (Table 4) with literature data for zebrafish, within the limits of the experimental error. Alsop et al. [74] recorded in the carcass of zebrafish a mean value of As content of $2.19 \pm 0.19 \mathrm{mg} \mathrm{kg}^{-1} \mathrm{ww}$, a value similar to that found in this study $\left(0.54-2.1 \mathrm{mg} \mathrm{kg}^{-1} \mathrm{ww}\right)$.

$\mathrm{Ni}$ content in zebrafish specimens did not seem to be correlated to the Ni level in diets, because, as the Ni content in the insect-based diets decreases, a general increase in the Ni content in the fish was observed. In line with this result, Alsop et al. [74] also demonstrated that there were no differences in tissue Ni concentrations in zebrafish fed with a control diet or a Ni-enriched diet. To explain the obtained results, the increased bioavailability of Ni in insect-based diets compared to the control diet could be called into question, as previously proposed for lead. However, the existence has been demonstrated in zebrafish of several very complex stimulatory and inhibitory interactions among metals, such as $\mathrm{Cd}, \mathrm{Pb}, \mathrm{Cu}$, $\mathrm{Zn}$, and $\mathrm{Ni}$, during the uptake process [112]. Therefore, the apparent strange behavior of $\mathrm{Ni}$ could be due to different causes, for which this study did not provide enough information, and further investigation is needed.

Concerning the BAF, all the considered specimens showed a value $>1$, except for larvae fed with the Control diet and the Hi25 diet. The bioaccumulation capacity is greater in juveniles (BAF 2.2-39) and adults (BAF 3.5-42) than in larvae (0.49-27). For all life stages, we observed an exponential growth of BAF with an increasing percentage of the inclusion of Hi meal in the diet, from the specimens fed with Hi25 to those fed with the Hi100 diet. This trend may point to Ni's ability to bioaccumulate in zebrafish, as evidenced for $\mathrm{Hg}$ and As too. Several studies have demonstrated Ni accumulation in various fish tissues, including gill, kidney, skeleton, white muscle, liver, brain, heart, stomach, intestine, skin, scales, and gonads, following either waterborne or dietary $\mathrm{Ni}$ exposure $[29,113]$.

$\mathrm{Ni}$ was the metal present in the highest concentrations in zebrafish, but $\mathrm{Ni}$ is not considered in the laws that limit PTEs content in feed and food. Considering the level of this metal detected in zebrafish and taking into account its toxicity, the authors think that it would be interesting to deepen this topic and suggest the scientific community should identify and fix specific limits for Ni content both in feed and food. 
Table 4. Potentially toxic elements (PTEs) content in zebrafish (Danio rerio) laboratory cultured: comparison with literature data.

\begin{tabular}{|c|c|c|c|c|}
\hline Life Stage & Organ & Exposure & $\begin{array}{c}\text { PTEs Content } \\
\left(\mathrm{mg} \mathrm{kg}^{-1} \text { ww or } \mathrm{dw}\right)\end{array}$ & Ref \\
\hline \multicolumn{5}{|c|}{$\mathrm{Cd}$} \\
\hline larvae & whole & natural & $\begin{array}{c}0.044-0.054(\mathrm{dw}) \\
0.0068-0.0082(\mathrm{ww})\end{array}$ & this study \\
\hline juvenile & carcass & & $\begin{array}{l}0.32-0.73(\mathrm{dw}) \\
0.08-0.16(\mathrm{ww})\end{array}$ & this study \\
\hline adult & carcass & & $\begin{array}{c}0.35-0.79(\mathrm{dw}) \\
0.11-0.25(\mathrm{ww})\end{array}$ & this study \\
\hline larvae & carcass & natural & $\sim 0.02(\mathrm{ww})$ & [33] \\
\hline adult & carcass & natural & $0.02(\mathrm{dw})$ & [33] \\
\hline adult & whole & natural & $1.5(\mathrm{dw})$ & [10] \\
\hline & & $10 \mathrm{ppt}$ & $\sim 8(\mathrm{dw})$ & \\
\hline adult & brain & natural & $0.4(w w)$ & [71] \\
\hline & & 1 ppm (2 days) & $20.2(\mathrm{ww})$ & \\
\hline adult & muscle & natural & $0.200 \pm 0.03(\mathrm{ww})$ & [75] \\
\hline & & $1.90 .6 \mathrm{ppb}$ & $0.18 \pm 0.04(w w)$ & \\
\hline & & $9.6 \pm 2.9 \mathrm{ppb}$ & $0.14 \pm 0.04(w w)$ & \\
\hline embryos & whole & & $\sim 0.2(\mathrm{dw})$ & [70] \\
\hline adult & liver and gills & river water & 4-27 (ww) & [68] \\
\hline adult & carcass & 0.5 ppm & $\sim 0.75(\mathrm{ww})$ & [83] \\
\hline \multicolumn{5}{|c|}{$\mathrm{Pb}$} \\
\hline larvae & whole & natural & $\begin{array}{c}0.16-0.66(\mathrm{dw}) \\
0.025-0.101(\mathrm{ww})\end{array}$ & this study \\
\hline juvenile & carcass & & $\begin{array}{c}0.23-1.19(\mathrm{dw}) \\
0.055-0.26(\mathrm{ww})\end{array}$ & this study \\
\hline adult & carcass & & $\begin{array}{c}0.23-1.30(\mathrm{dw}) \\
0.072-0.42(\mathrm{ww})\end{array}$ & this study \\
\hline adult & liver and gills & river water & $0.2-38(w w)$ & [68] \\
\hline adult & carcass & 1 ppm & $\sim 2(\mathrm{ww})$ & [83] \\
\hline \multicolumn{5}{|c|}{$\mathrm{Hg}$} \\
\hline larvae & whole & natural & $\begin{array}{c}0.009 \pm 0.003(\mathrm{dw}) \\
0.0013 \pm 0.0004(\mathrm{ww})\end{array}$ & this study \\
\hline juvenile & carcass & & $\begin{array}{l}0.079 \pm 0.003(\mathrm{dw}) \\
0.018 \pm 0.001(\mathrm{ww})\end{array}$ & this study \\
\hline adult & carcass & & $\begin{array}{l}0.102 \pm 0.005(\mathrm{dw}) \\
0.032 \pm 0.002(\mathrm{ww})\end{array}$ & this study \\
\hline adult & muscle & natural & next to $0(\mathrm{dw})$ & {$[76]$} \\
\hline & & 5 ppm (7 days) & $\sim 3(\mathrm{dw})$ & \\
\hline & & 5 ppm (21 days) & $\sim 8(\mathrm{dw})$ & \\
\hline & & 5 ppm (63 days) & $\sim 15(\mathrm{dw})$ & \\
\hline adult & muscle & $60 \pm 10 \mathrm{ppb}$ (diet) & $\sim 0.6(\mathrm{dw})$ & [72] \\
\hline & & $11.6 \pm 0.4 \mathrm{ppm}$ & $\sim 30(\mathrm{dw})$ & \\
\hline \multicolumn{5}{|c|}{ As } \\
\hline larvae & whole & natural & $\begin{array}{c}0.39-0.52(\mathrm{dw}) \\
0.060-0.080(\mathrm{ww})\end{array}$ & this study \\
\hline juvenile & carcass & & $\begin{array}{c}0.11-0.67(\mathrm{dw}) \\
0.026-0.16(\mathrm{ww})\end{array}$ & this study \\
\hline adult & carcass & & $\begin{array}{c}0.18-0.88(\mathrm{dw}) \\
0.058-0.27(\mathrm{ww})\end{array}$ & this study \\
\hline larvae & whole & 5 ppm & $0.4-0.5(w w)$ & [73] \\
\hline adult & muscle & 5 ppm & $0.4-0.5(w w)$ & \\
\hline adult & & natural & $0.94 \pm 0.08(\mathrm{dw})$ & [77] \\
\hline adult & carcass & natural & $0.27-0.39(\mathrm{dw})$ & [33] \\
\hline adult & liver and gills & river water & 4-40 (ww) & [68] \\
\hline \multicolumn{5}{|c|}{$\mathrm{Ni}$} \\
\hline larvae & whole & natural & $\begin{array}{c}0.52-3.3(\mathrm{dw}) \\
0.089-0.50(\mathrm{ww})\end{array}$ & this study \\
\hline juvenile & carcass & & $\begin{array}{c}0.19-4.7(\mathrm{dw}) \\
0.27-1.03(\mathrm{ww})\end{array}$ & this study \\
\hline adult & carcass & & $\begin{array}{l}1.7-6.90(\mathrm{dw}) \\
0.54-2.1(\mathrm{ww})\end{array}$ & this study \\
\hline adult & muscle & natural & $0.79 \pm 0.03(w w)$ & [74] \\
\hline & carcass & natural & $2.19 \pm 0.19(w w)$ & \\
\hline
\end{tabular}




\section{Materials and Methods}

\subsection{Ethics}

All procedures involving animals were conducted in line with Italian legislation and approved by the Ethics Committee of Università Politecnica delle Marche and the Italian Ministry of Health (626/2018-PR).

\subsection{Fish Diet Production}

Fish diet production was performed according to Zarantoniello et al. [78]. Briefly, full-fat BSF prepupae, reared on a substrate based on coffee silverskin, a coffee industry by-product provided by Saccaria Caffe' S.R.L. (Marina di Montemarciano, Ancona, Italy), added with $10 \%(w / w)$ of the microalga Schizochytrium sp (for details, see [58]), were used to prepare the experimental diets. The Control diet (CTRL) was prepared, according to a commercially available standard diet for zebrafish (Zebrafeed, Sparos Ltd., Olhão, Portugal), with fish meal (FM) and fish oil (FO), wheat gluten, and pea protein concentrates as major ingredients. Insect-based diets were prepared by including different percentage of insect meal $(25 \%, 50 \%, 75 \%$, and $100 \%)$ in substitution of the marine source (FM and FO) in the Control diet (CTRL), to obtain Hi25, Hi50, Hi75, and Hi100 diets, respectively, according to [78].

\subsection{Experimental Design}

Zebrafish specimens were reared as in [78]. Briefly, larvae (collected from embryos) were maintained for $48 \mathrm{~h}$ in a Tecniplast system (Varese, Italy) at the following conditions: $28{ }^{\circ} \mathrm{C}$ temperature, $\mathrm{pH} 7.0, \mathrm{NO}_{2}$ and $\mathrm{NH}_{3}$ concentrations $<0.01 \mathrm{mg} / \mathrm{L}, \mathrm{NO}_{3}$ concentration $<10 \mathrm{mg} / \mathrm{L}$, and a 12L/12D photoperiod. The water in the larval tanks was gently replaced 10 times a day by a dripping system. At 30 days post spawning, fish were gently transferred in big tanks (80 L) equipped with mechanical and biological filtration (Panaque, Capranica, VT, Italy). The duration of the feeding trial was 180 days. Experimental diets were administered starting from 5 to 180 days post fertilization (dpf) twice a day and, in addition, from 5 to $10 \mathrm{dpf}$, all groups were fed (one feeding in the morning) on the rotifer Brachionus plicatilis (5 ind / $\mathrm{mL}$ ) according to Lawrence et al. [114]. Fish specimens were sampled at 21 (larvae, L), 60 (juveniles, J), and 180 (adults, A) dpf, euthanized with a lethal dose of MS222 $\left(1 \mathrm{~g} \mathrm{~L}^{-1}\right)$, and properly stored for further analyses.

\subsection{Chemical Analyses and Quality Control}

A clean room laboratory ISO 14644-1 Class 6, with areas at ISO Class 5 under laminar flow, was used for sample treatment; all the materials needed to handle samples followed decontamination procedures to avoid any sample contamination, as described in Truzzi et al. [16] and Illuminati et al. [115].

Samples of diets and zebrafish were minced, homogenized (homogenizer MZ 4110, DCG Eltronic, Monza, Italy), and divided into aliquots of $0.5 \mathrm{~g}$ each. To determine the moisture, samples were accurately weighed with the analytical balance AT261 (Mettler Toledo, Greifensee, Switzerland) and freeze-dried (Edwards EF4 modulyo, Crawley, Sussex, England) until constant weight $( \pm 0.2 \mathrm{mg})$. Analyses were carried out on three aliquots per sample. For the determination of $\mathrm{Cd}, \mathrm{Pb}, \mathrm{As}$, and $\mathrm{Ni}$, samples were mineralized in an ultrapure $(65 \% w / v)$ nitric acid $\mathrm{HNO}_{3}$ and $30 \% v / v \mathrm{H}_{2} \mathrm{O}_{2}$ (Merk, Darmstadt, Germany) mixture in a microwave-accelerated reaction system, MARS-X, $1500 \mathrm{~W}$ (CEM, Mathews, NC, USA); operational parameters were as in Truzzi et al. [50]. Agilent DUO 240FS atomic absorption spectrometer (Agilent, Santa Clara, CA 95051, USA) equipped with a graphite furnace (GTA120 Graphite Tube Atomizer) and a Zeeman-effect background correction (GF-AAS) was used for the quantitative determinations of $\mathrm{Cd}, \mathrm{Pb}, \mathrm{Ni}$, and As. Analytical methodology and instrumental parameters were described in [50]. Total mercury content was quantified by thermal decomposition amalgamation atomic absorption spectrometry using a direct mercury analyzer (DMA-1, Milestone, Sorisole, BG, Italy), according to [116]. The homogenized samples were weighed directly into quartz containers. The optimized 
reading conditions for mercury determination in fish were the same as for $\mathrm{Hg}$ determination in feed and in insects [50]. A calibration curve technique was used for the quantification of mercury content [41].

All analyses were carried out in triplicate. Analytical quality control was achieved using the certified reference material DORM-2 dogfish muscle (National Research Council of Canada). Results (Table 5) were in good agreement with the certified values, and the standard deviation was low, proving the good repeatability of the methods.

Table 5. Accuracy test using certified reference material DORM-2 (dogfish muscle), NRC Canada. Data are expressed in $\mathrm{mg} \mathrm{kg}^{-1}$.

\begin{tabular}{ccccc}
\hline Element & Analytical Method & Analytical Result $(\boldsymbol{n}=\mathbf{9 )}$ & Certified Value & $\boldsymbol{\Delta} \mathbf{( \% )}$ \\
\hline $\mathrm{Cd}$ & GF-AAS & $0.041 \pm 0.005$ & $0.043 \pm 0.008$ & -4.7 \\
$\mathrm{~Pb}$ & GF-AAS & $0.067 \pm 0.003$ & $0.065 \pm 0.007$ & +3.1 \\
$\mathrm{As}$ & GF-AAS & $17.6 \pm 0.5$ & $18 \pm 1.1$ & -2.2 \\
$\mathrm{Ni}$ & GF-AAS & $18.8 \pm 0.9$ & $19.4 \pm 3.1$ & -3.1 \\
$\mathrm{Hg}$ & DMA-1 & $4.30 \pm 0.2$ & $4.64 \pm 0.2$ & -6.1 \\
\hline
\end{tabular}

Three aliquots of water were collected from each tank to determine the total PTEs. Water samples were diluted with ultrapure grade $\mathrm{HCl}$ 2\% (Carlo Erba, Milan, Italy) (v/v) and then $\mathrm{Hg}, \mathrm{Pb}, \mathrm{Cd}$, and As were determinated with a AFS Titan 8220 spectrofluorometer (Fulltech Instruments, Rome, Italy). Argon 5.0 (99.999\% purity) was used as a carrier gas. $\mathrm{HCl} 2 \%$ (for $\mathrm{Cd}$ and $\mathrm{Pb}$ determination) or $5 \%$ (for $\mathrm{Hg}$ and As determination) (v/v) was used as the sample carrier. Reductant agents to produce metal hydrides were $\mathrm{H}_{4} \mathrm{BNa} 0.05 \%$ ( $\geq 98.0 \%$, Merck, Kenilworth, New Jersey, United States) in $\mathrm{NaOH} \mathrm{0.4 \%} \mathrm{(m/v)} \mathrm{(99.99 \% ,}$ metal basis, Thermo Fisher, Kandel, Germany) for $\mathrm{Hg}$ determination; $\mathrm{H}_{4} \mathrm{BNa} 2.0 \%$ in $\mathrm{NaOH}$ $0.7 \%$ and $\mathrm{K}_{3} \mathrm{Fe}(\mathrm{CN})_{6} 1.0 \%(\mathrm{~m} / \mathrm{v})$ (RPE grade, Carlo Erba, Milan, Italy) for Pb determination; $\mathrm{H}_{4} \mathrm{BNa} 4.0 \%$ in $\mathrm{NaOH} 0.4 \%, \mathrm{CH}_{4} \mathrm{~N}_{2} \mathrm{~S} 1.0 \%(\mathrm{~m} / \mathrm{v})$ (RPE grade, Carlo Erba, Milan, Italy), and $\mathrm{CoCl}_{2} 1.0 \mu \mathrm{g} \mathrm{mL}^{-1}$ (97\% Thermo Fisher, Kandel, Germany) for Cd determination; and $\mathrm{H}_{4} \mathrm{BNa} 2 \%$ in $\mathrm{NaOH} 0.5 \%(\mathrm{~m} / \mathrm{v})$ for As determination. AFS instrumental parameters are reported in Table 6. For As determination, samples were diluted with $\mathrm{HCl} \mathrm{10 \%}(v / v), 1 \% \mathrm{KI}$ $(m / v)$ (RPE grade, Carlo Erba, Milan, Italy), and 0.5\% ascorbic acid $(m / v)$ (RPE grade, Carlo Erba, Milan, Italy) and analyzed after $1 \mathrm{~h}$. The levels of metals were quantified with a calibration curve.

Table 6. AFS Titan 8220 spectrofluorometer analytical parameters.

\begin{tabular}{|c|c|c|c|c|}
\hline Instrumental Parameter & $\mathrm{Hg}$ & $\mathrm{Pb}$ & Cd & As \\
\hline Lamp current (mA) & $30 / 0$ & $80 / 40$ & $60 / 30$ & $60 / 30$ \\
\hline PMT (Volts) & 275 & 285 & 280 & 320 \\
\hline Carrier gas $\left(\mathrm{mL} \min ^{-1}\right)$ & 300 & 300 & 500 & 300 \\
\hline Shield gas $\left(\mathrm{mL} \min ^{-1}\right)$ & 1000 & 800 & 800 & 800 \\
\hline Reading time (s) & 15 & 15 & 15 & 15 \\
\hline Delay time $(\mathrm{s})$ & 0.5 & 0.5 & 0.5 & 0.5 \\
\hline Blank judgement Value (if) & 5 & 10 & 10 & 10 \\
\hline Torch height $(\mathrm{mm})$ & 10 & 8 & 8 & 8 \\
\hline IFS Step $(\mathrm{s} \times \mathrm{rpm}, \mathrm{a}=$ analyte; & (a) $10 \times 100$ & (a) $10 \times 100$ & (a) $10 \times 100$ & (a) $10 \times 100$ \\
\hline $\mathrm{c}=$ carrier $; \mathrm{r}=$ reading $)$ & (c) $(\mathrm{r}) 16 \times 120$ & (c) $(\mathrm{r}) 16 \times 120$ & (c) $(\mathrm{r}) 16 \times 120$ & (c) $(\mathrm{r}) 18 \times 120$ \\
\hline
\end{tabular}

For Ni determination, samples were mineralized with $\mathrm{HNO}_{3} 0.2 \%(v / v)$ for 30 min at $90{ }^{\circ} \mathrm{C}$ in decontaminated centrifuge tubes and analyzed on a GF-AAS instrument as for diets and fish. Instrumental LOD and LOQ and reference material checks are reported in Table 7. Mineralized DORM-2 (dogfish muscle), NASS-6 (seawater reference material for trace metals), and SLEW-3 (estuarine water reference material for trace metals) (National Research Council of Canada) were used as certified reference material. 
Table 7. Instrumental LOD and LOQ and quality control check (certified reference material, CRM, DORM-2, NASS-6, and SLEW-3 (NRC CNRC, Ottawa, ON, Canada) for water analysis.

\begin{tabular}{|c|c|c|c|c|c|c|}
\hline \multirow[b]{2}{*}{ Element } & \multirow[b]{2}{*}{ Instrument } & \multirow[b]{2}{*}{ LOD $\left(\mu \mathrm{g} \cdot \mathrm{L}^{-1}\right)$} & \multirow[b]{2}{*}{$\mathrm{LOQ}\left(\mu \mathrm{g} \cdot \mathrm{L}^{-1}\right)$} & \multicolumn{3}{|c|}{ CRM } \\
\hline & & & & Name & Certified Value $\left(\mu \mathrm{g} \mathrm{L}^{-1}\right)$ & Measured Value $\left(\mu \mathrm{g}^{-1}\right)$ \\
\hline $\mathrm{Hg}$ & AFS & 0.0006 & 0.006 & DORM-2 & $4.64 \pm 0.26^{\mathrm{a}}$ & $4.84 \pm 0.22$ \\
\hline $\mathrm{Pb}$ & AFS & 0.03 & 3 & DORM-2 & $0.065 \pm 0.007^{\mathrm{a}}$ & $0.060 \pm 0.008$ \\
\hline $\mathrm{Cd}$ & AFS & 0.0005 & 0.005 & NASS-6 & $0.0311 \pm 0.0019$ & $0.031 \pm 0.008$ \\
\hline As & AFS & 0.01 & 0.13 & SLEW-3 & $1.36 \pm 0.09$ & $1.47 \pm 0.27$ \\
\hline $\mathrm{Ni}$ & GFAAS & 0.144 & 1.440 & SLEW-3 & $1.23 \pm 0.07$ & $1220 \pm 390$ \\
\hline
\end{tabular}

a Accuracy test carried out on mineralized CRM. Value expressed in $\mathrm{mg} \mathrm{kg}^{-1}$. AFS: AFS Titan 8220 spectrofluorometer. GF-AAS: Agilent DUO 240FS atomic absorption spectrometer equipped with a graphite furnace.

\subsection{Bioaccumulation Factor}

The bioaccumulation factor (BAF) was calculated on a dry weight ( $\mathrm{dw}$ ) basis [49], as the ratio between metal concentration in the organism and metal concentration in the feed provided. A BAF greater than 1 suggests bioaccumulation of the element from the diet into the fish.

\subsection{Statistical Analysis}

Data are expressed as mean \pm standard deviation (SD) of the performed replications. After testing the homogeneity of variance with Levene's test, the normal distribution of data was verified. Therefore, data were subjected to the one-way analysis of variance (ANOVA), followed by the multiple range test [117], to evaluate significant differences among groups at the $95 \%$ confidence level. When the ANOVA test gave a $p$-value equal to 0.0000 , in the text it was indicated as $p<0.0001$. All statistical treatments were performed using STATGRAPHICS 19 Centurion [118].

\section{Conclusions}

The substitution of FM and FO with Hermetia illucens meal in experimental diets led to a reduction in the content of some PTEs, such as $\mathrm{Pb}, \mathrm{As}$, and $\mathrm{Ni}$, with concentrations for all studied PTEs below the legal limit of undesirable substances in animal feed given in [45] (however, there are no limits for Ni). Moreover, this study shows that the PTEs content of zebrafish specimens can be influenced both by the type of diet administered and by the life stage of the animal itself. Zebrafish fed with Hi meal-based diets showed a very low content of potentially toxic elements. The metal present in higher concentration, $\mathrm{Ni}$, deserves particular attention because of its toxicity and the lack of a legal limit for its content both in feed and in food. However, results suggested that the strict control of the presence of contaminants throughout the production chain, from the growth substrate of insects to insects, to fish feed, and, finally, to fish specimens, in view of the possible use of insects in fish feed, could make aquaculture an environmentally sustainable and safe sector. This research demonstrates the possibility of using Hi prepupae raised on substrates based on silverskin (coffee-roasting waste) and 10\% microalgae Schizocytrium sp. as an aquafeed ingredient, without exposing fish to a chemical risk. Consequently, in perspective, this study paves the way for the use of eco-sustainable insect-based diets in aquaculture for the breeding of edible fish species, after a careful assessment of the chemical risk associated with them, to avoid risks to human health.

Author Contributions: Conceptualization, C.T., M.Z. and I.O.; methodology, G.S. and M.Z.; validation, F.G. and L.G.; formal analysis, L.G. and F.G.; resources, C.T. and I.O.; data curation, A.A. and S.I.; writing - original draft preparation, C.T. and F.G.; writing-review and editing, I.O. and S.I.; supervision, C.T. and S.I.; project administration, I.O. and C.T.; funding acquisition, I.O. and C.T. All authors have read and agreed to the published version of the manuscript. 
Funding: This work was supported by Fondazione Cariverona, Ricerca Scientifica 2017, project NUTRIFISH, code n. 2017.0571, to Ike Olivotto, and by Polytechnic University of Marche, Ricerca Scientifica di Ateneo, to Cristina Truzzi.

Institutional Review Board Statement: All procedures involving animals were conducted in line with the Italian legislation and approved by the Ethics Committee of Università Politecnica delle Marche and the Italian Ministry of Health (626/2018-PR).

Conflicts of Interest: The authors declare no conflict of interest.

Sample Availability: Samples of the compounds are not available from the authors.

\section{References}

1. FAO-GFCM. Fishery and Aquaculture Statistics. GFCM Capture Production 1970-2019; FAO Fisheries and Aquaculture Department: Rome, Italy, 2020. Available online: https:/ / www.fao.org/gfcm/data/capture-production/en/ (accessed on 24 November 2021).

2. FAO. The State of World Fisheries and Aquaculture 2018-Meeting the Sustainable Development Goals; Food and Agricultural Organization: Rome, Italy, 2018.

3. EFSA Scientific Committee. Risk Profile Related to Production and Consumption of Insects as Food and Feed. EFSA J. 2015, 13, 4257. [CrossRef]

4. Makkar, H.P.S.; Tran, G.; Heuzé, V.; Ankers, P. State-of-the-Art on Use of Insects as Animal Feed. Anim. Feed Sci. Technol. 2014, 197, 1-33. [CrossRef]

5. Van Huis, A.; Oonincx, D.G.A.B. The Environmental Sustainability of Insects as Food and Feed. A Review. Agron. Sustain. Dev. 2017, 37, 43. [CrossRef]

6. Nguyen, T.T.X.; Tomberlin, J.K.; Vanlaerhoven, S. Ability of Black Soldier Fly (Diptera: Stratiomyidae) Larvae to Recycle Food Waste. Environ. Entomol. 2015, 44, 406-410. [CrossRef]

7. Fowles, T.M.; Nansen, C. Insect-Based Bioconversion: Value from Food Waste. In Food Waste Management: Solving the Wicked Problem; Springer International Publishing: Cham, Switzerland, 2019; pp. 321-346, ISBN 9783030205614.

8. Olsen, R.L.; Hasan, M.R. A Limited Supply of Fishmeal: Impact on Future Increases in Global Aquaculture Production. Trends Food Sci. Technol. 2012, 27, 120-128. [CrossRef]

9. Henry, M.; Gasco, L.; Piccolo, G.; Fountoulaki, E. Review on the Use of Insects in the Diet of Farmed Fish: Past and Future. Anim. Feed Sci. Technol. 2015, 203, 1-22. [CrossRef]

10. Måge, A.; Julshamn, K.; Hemre, G.I.; Lunestad, B.T. Norwegian Surveillance Program on Feed for Fish and Other Aquatic Organisms; Annual Report 2007; National Institute of Nutrition and Seafood Research: Bergen, Norway, 2008. Available online: www. mattilsynet.no; www.nifes.no (accessed on 24 November 2021). (In Norwegian)

11. Amlund, H.; Berntssen, M.H.G.; Lunestad, B.T.; Lundebye, A.K. Aquaculture Feed Contamination by Persistent Organic Pollutants, Heavy Metals, Additives and Drug Residues. In Animal Feed Contamination: Effects on Livestock and Food Safety; Elsevier: Amsterdam, The Netherlands, 2012; pp. 205-229, ISBN 9781845697259.

12. Do'rea, J.G. Fish Meal in Animal Feed and Human Exposure to Persistent Bioaccumulative and Toxic Substances. J. Food Prot. 2006, 69, 2777-2785. [CrossRef]

13. Sissener, N.H.; Julshamn, K.; Espe, M.; Lunestad, B.T.; Hemre, G.I.; Waagbø, R.; Måge, A. Surveillance of Selected Nutrients, Additives and Undesirables in Commercial Norwegian Fish Feeds in the Years 2000-2010. Aquac. Nutr. 2013, 19, 555-572. [CrossRef]

14. Berntssen, M.H.G.; Julshamn, K.; Lundebye, A.K. Chemical Contaminants in Aquafeeds and Atlantic Salmon (Salmo salar) Following the Use of Traditional- versus Alternative Feed Ingredients. Chemosphere 2010, 78, 637-646. [CrossRef]

15. Diener, S.; Zurbrügg, C.; Tockner, K. Bioaccumulation of Heavy Metals in the Black Soldier Fly, Hermetia illucens and Effects on Its Life Cycle. J. Insects Food Feed 2015, 1, 261-270. [CrossRef]

16. Truzzi, C.; Annibaldi, A.; Girolametti, F.; Giovannini, L.; Riolo, P.; Ruschioni, S.; Olivotto, I.; Illuminati, S. A Chemically Safe Way to Produce Insect Biomass for Possible Application in Feed and Food Production. Int. J. Environ. Res. Public Health 2020, $17,2121$. [CrossRef]

17. Proc, K.; Bulak, P.; Wiącek, D.; Bieganowski, A. Hermetia Illucens Exhibits Bioaccumulative Potential for 15 Different ElementsImplications for Feed and Food Production. Sci. Total Environ. 2020, 723, 138125. [CrossRef]

18. Zanoli, P.; Rossi, T.; Vaccari, G.; Giacobazzi, A.; Truzzi, C.; Avallone, R.; Ventura, A. Effetti Di Deficit Ed Accumulo Di Metalli Pesanti Sulla Funzionalità Del Sistema Nervoso Centrale. In Nutrizione e Cervello; Pythagora Press: Milan, Italy, 1992.

19. Tchounwou, P.B.; Yedjou, C.G.; Patlolla, A.K.; Sutton, D.J. Heavy Metal Toxicity and the Environment. EXS 2012, 101, 133-164. [CrossRef]

20. Illuminati, S.; Annibaldi, A.; Truzzi, C.; Tercier-Waeber, M.L.; Nöel, S.; Braungardt, C.B.; Achterberg, E.P.; Howell, K.A.; Turner, D.; Marini, M.; et al. In-Situ Trace Metal (Cd, Pb, Cu) Speciation along the Po River Plume (Northern Adriatic Sea) Using Submersible Systems. Mar. Chem. 2019, 212, 47-63. [CrossRef]

21. Sethy, K.; Pati, S.; Jena, D.; Mishra, C.K. Heavy Metal Toxicity in Animals: A Review. Pharma Innov. J. 2020, 9, $134-137$. 
22. Jin, M.; Yuan, H.; Liu, B.; Peng, J.; Xu, L.; Yang, D. Review of the Distribution and Detection Methods of Heavy Metals in the Environment. Anal. Methods 2020, 12, 5747-5766. [CrossRef]

23. International Agency for Research on Cancer. Agents Classified by the IARC Monographs, Volumes 1-130; International Agency for Research on Cancer: Lyon, France, 2021.

24. Godt, J.; Scheidig, F.; Grosse-Siestrup, C.; Esche, V.; Brandenburg, P.; Reich, A.; Groneberg, D.A. The Toxicity of Cadmium and Resulting Hazards for Human Health. J. Occup. Med. Toxicol. 2006, 1, 22. [CrossRef]

25. Goyer, R.A. Lead Toxicity: From Overt to Subclinical to Subtle Health Effects. Environ. Health Perspect. 1990, 86, 177-181. [CrossRef]

26. Zahir, F.; Rizwi, S.J.; Haq, S.K.; Khan, R.H. Low Dose Mercury Toxicity and Human Health. Environ. Toxicol. Pharmacol. 2005, 20, 351-360. [CrossRef]

27. Bibi, S.; Kamran, M.A.; Sultana, J.; Farooqi, A. Occurrence and Methods to Remove Arsenic and Fluoride Contamination in Water. Environ. Chem. Lett. 2017, 15, 125-149. [CrossRef]

28. Cempel, M.; Nikel, G. Nickel: A Review of Its Sources and Environmental Toxicology. Pol. J. Environ. Stud. 2006, 15, 375-382.

29. Wood, C.M.; Farrell, A.P.; Brauner, C.J. Homeostasis and Toxicology of Essential Metals; Academic Press: Cambridge, MA, USA, 2012; Volume 31A.

30. Wood, C.M.; Farrell, A.P.; Brauner, C.J. Homeostasis and Toxicology of Non-Essential Metals; Academic Press: Cambridge, MA, USA, 2012; Volume 31B.

31. Luoma, S.N.; Rainbow, P.S. Why Is Metal Bioaccumulation so Variable? Biodynamics as a Unifying Concept. Environ. Sci. Technol. 2005, 39, 1921-1931. [CrossRef] [PubMed]

32. Boyle, D.; Hogstrand, C.; Bury, N.R. Physiological Response to a Metal-Contaminated Invertebrate Diet in Zebrafish: Importance of Metal Speciation and Regulation of Metal Transport Pathways. Aquat. Toxicol. 2011, 105, 21-28. [CrossRef] [PubMed]

33. Boyle, D.; Brix, K.V.; Amlund, H.; Lundebye, A.K.; Hogstrand, C.; Bury, N.R. Natural Arsenic Contaminated Diets Perturb Reproduction in Fish. Environ. Sci. Technol. 2008, 42, 5354-5360. [CrossRef]

34. Ali, H.; Khan, E.; Ilahi, I. Environmental Chemistry and Ecotoxicology of Hazardous Heavy Metals: Environmental Persistence, Toxicity, and Bioaccumulation. J. Chem. 2019, 2019, 6730305. [CrossRef]

35. DeForest, D.K.; Brix, K.V.; Adams, W.J. Assessing Metal Bioaccumulation in Aquatic Environments: The Inverse Relationship between Bioaccumulation Factors, Trophic Transfer Factors and Exposure Concentration. Aquat. Toxicol. 2007, 84, 236-246. [CrossRef]

36. Zhuang, P.; Li, Z.; McBride, M.B.; Zou, B.; Wang, G. Health Risk Assessment for Consumption of Fish Originating from Ponds near Dabaoshan Mine, South China. Environ. Sci. Pollut. Res. 2013, 20, 5844-5854. [CrossRef]

37. Rahman, M.S.; Molla, A.H.; Saha, N.; Rahman, A. Study on Heavy Metals Levels and Its Risk Assessment in Some Edible Fishes from Bangshi River, Savar, Dhaka, Bangladesh. Food Chem. 2012, 134, 1847-1854. [CrossRef]

38. Girolametti, F.; Annibaldi, A.; Carnevali, O.; Pignalosa, P.; Illuminati, S.; Truzzi, C. Potential Toxic Elements (PTEs) in Wild and Farmed Atlantic Bluefin Tuna (Thunnus thynnus) from Mediterranean Sea: Risks and Benefits for Human Consumption. Food Control 2021, 125, 108012. [CrossRef]

39. Fakhri, Y.; Mohseni-Bandpei, A.; Oliveri Conti, G.; Ferrante, M.; Cristaldi, A.; Jeihooni, A.K.; Karimi Dehkordi, M.; Alinejad, A.; Rasoulzadeh, H.; Mohseni, S.M.; et al. Systematic Review and Health Risk Assessment of Arsenic and Lead in the Fished Shrimps from the Persian Gulf. Food Chem. Toxicol. 2018, 113, 278-286. [CrossRef]

40. Rahmani, J.; Fakhri, Y.; Shahsavani, A.; Bahmani, Z.; Urbina, M.A.; Chirumbolo, S.; Keramati, H.; Moradi, B.; Bay, A.; Bjørklund, G A Systematic Review and Meta-Analysis of Metal Concentrations in Canned Tuna Fish in Iran and Human Health Risk Assessment. Food Chem. Toxicol. 2018, 118, 753-765. [CrossRef]

41. Annibaldi, A.; Truzzi, C.; Carnevali, O.; Pignalosa, P.; Api, M.; Scarponi, G.; Illuminati, S. Determination of Hg in Farmed and Wild Atlantic Bluefin Tuna (Thunnus thynnus L.) Muscle. Molecules 2019, 24, 1273. [CrossRef]

42. Ali, H.; Khan, E. Bioaccumulation of Non-Essential Hazardous Heavy Metals and Metalloids in Freshwater Fish. Risk to Human Health. Environ. Chem. Lett. 2018, 16, 903-917. [CrossRef]

43. Decreto Legislativo 2 Febbraio 2001, n. 31. Attuazione Della Direttiva 98/83/CE Relativa Alla Qualita' Delle Acque Destinate al Consumo Umano. Pubblicato Nella Gazzetta Ufficiale n. 52 Del 3 Marzo 2001—Supplemento Ordinario n. 41. Available online: https:/ / www.camera.it/parlam/leggi/deleghe/01031dl.htm (accessed on 20 October 2020).

44. European Parliament; European Council. Directive 2000/60/EC of the European Parliament and of the Council of 23 October 2000 Establishing a Framework for Community Action in the Field of Water Policy. Off. J. Eur. Communities 2000, L327, 1-72.

45. European Parliament; European Council. Directive 2002/32/EC of 7 May 2002 on Undesirable Substances in Animal Feed. Off. J. Eur. Communities 2002, L140, 10-21.

46. European Commission. Commission Regulation (EC) No 1881/2006 of 19 December 2006 Setting Maximum Levels for Certain Contaminants in Foodstuffs. Off. J. Eur. Union 2006, L364, 5-24.

47. European Parliament; European Council. Commission Regulation (EU) No 420/2011 29 April 2011 Amending Regulation (EC) No 1881/2006 Setting Maximum Levels for Certain Contaminants in Foodstuffs. Off. J. Eur. Communities 2011, L111, 3-6.

48. European Parliament; European Council. Commission Regulation (EU) No 1006/2011 25 June 2015 Amending Regulation (EC) No 1881/2006 as Regards Maximum Levels of Inorganic Arsenic in Foodstuffs. Off. J. Eur. Communities 2015, L161, 14-16. 
49. Van der Fels-Klerx, H.J.; Camenzuli, L.; van der Lee, M.K.; Oonincx, D.G.A.B. Uptake of Cadmium, Lead and Arsenic by Tenebrio molitor and Hermetia illucens from Contaminated Substrates. PLoS ONE 2016, 11, e0166186. [CrossRef]

50. Truzzi, C.; Illuminati, S.; Girolametti, F.; Antonucci, M.; Scarponi, G.; Ruschioni, S.; Riolo, P.; Annibaldi, A. Influence of Feeding Substrates on the Presence of Toxic Metals $(\mathrm{Cd}, \mathrm{Pb}, \mathrm{Ni}$, as, $\mathrm{Hg}$ ) in Larvae of Tenebrio molitor: Risk Assessment for Human Consumption. Int. J. Environ. Res. Public Health 2019, 16, 4815. [CrossRef]

51. Barroso, F.G.; de Haro, C.; Sánchez-Muros, M.J.; Venegas, E.; Martínez-Sánchez, A.; Pérez-Bañón, C. The Potential of Various Insect Species for Use as Food for Fish. Aquaculture 2014, 422-423, 193-201. [CrossRef]

52. Randazzo, B.; Zarantoniello, M.; Gioacchini, G.; Cardinaletti, G.; Belloni, A.; Giorgini, E.; Faccenda, F.; Cerri, R.; Tibaldi, E.; Olivotto, I. Physiological Response of Rainbow Trout (Oncorhynchus mykiss) to Graded Levels of Hermetia illucens or Poultry by-Product Meals as Single or Combined Substitute Ingredients to Dietary Plant Proteins. Aquaculture 2021, 538, 736550. [CrossRef]

53. Lock, E.-J.; Biancarosa, I.; Gasco, L. Insects as Raw Materials in Compound Feed for Aquaculture. In Edible Insects in Sustainable Food Systems; Springer International Publishing: Cham, Switzerland, 2018; pp. 263-276.

54. Barragan-Fonseca, K.B.; Dicke, M.; van Loon, J.J.A. Nutritional Value of the Black Soldier Fly (Hermetia illucens L.) and Its Suitability as Animal Feed-A Review. J. Insects Food Feed 2017, 3, 105-120. [CrossRef]

55. Borgogno, M.; Dinnella, C.; Iaconisi, V.; Fusi, R.; Scarpaleggia, C.; Schiavone, A.; Monteleone, E.; Gasco, L.; Parisi, G. Inclusion of Hermetia Illucens Larvae Meal on Rainbow Trout (Oncorhynchus mykiss) Feed: Effect on Sensory Profile According to Static and Dynamic Evaluations. J. Sci. Food Agric. 2017, 97, 3402-3411. [CrossRef]

56. Zhou, J.S.; Liu, S.S.; Ji, H.; Yu, H.B. Effect of Replacing Dietary Fish Meal with Black Soldier Fly Larvae Meal on Growth and Fatty Acid Composition of Jian Carp (Cyprinus carpio Var. Jian). Aquac. Nutr. 2018, 24, 424-433. [CrossRef]

57. Biancarosa, I.; Sele, V.; Belghit, I.; Ørnsrud, R.; Lock, E.J.; Amlund, H. Replacing Fish Meal with Insect Meal in the Diet of Atlantic Salmon (Salmo Salar) Does Not Impact the Amount of Contaminants in the Feed and It Lowers Accumulation of Arsenic in the Fillet. Food Addit. Contam. Part A Chem. Anal. Control Expo. Risk Assess. 2019, 36, 1191-1205. [CrossRef]

58. Truzzi, C.; Giorgini, E.; Annibaldi, A.; Antonucci, M.; Illuminati, S.; Scarponi, G.; Riolo, P.; Isidoro, N.; Conti, C.; Zarantoniello, M.; et al. Fatty Acids Profile of Black Soldier Fly (Hermetia illucens): Influence of Feeding Substrate Based on Coffee-Waste Silverskin Enriched with Microalgae. Anim. Feed Sci. Technol. 2020, 259, 114309. [CrossRef]

59. Zarantoniello, M.; Randazzo, B.; Cardinaletti, G.; Truzzi, C.; Chemello, G.; Riolo, P.; Olivotto, I. Possible Dietary Effects of Insect-Based Diets across Zebrafish (Danio rerio) Generations: A Multidisciplinary Study on the Larval Phase. Animals 2021, 11, 751. [CrossRef]

60. Dahm, R.; Geisler, R. Learning from Small Fry: The Zebrafish as a Genetic Model Organism for Aquaculture Fish Species. Mar. Biotechnol. 2006, 8, 329-345. [CrossRef]

61. Hoo, J.Y.; Kumari, Y.; Shaikh, M.F.; Hue, S.M.; Goh, B.H. Zebrafish: A Versatile Animal Model for Fertility Research. BioMed Res. Int. 2016, 2016, 9732780. [CrossRef]

62. Grunwald, D.J.; Eisen, J.S. Headwaters of the Zebrafish-Emergence of a New Model Vertebrate. Nat. Rev. Genet. 2002, 3, 717-724. [CrossRef] [PubMed]

63. Piccinetti, C.C.; Migliarini, B.; Olivotto, I.; Simoniello, M.P.; Giorgini, E.; Carnevali, O. Melatonin and Peripheral Circuitries: Insights on Appetite and Metabolism in Danio rerio. Zebrafish 2013, 10, 275-282. [CrossRef] [PubMed]

64. Piccinetti, C.C.; Montis, C.; Bonini, M.; Laurà, R.; Guerrera, M.C.; Radaelli, G.; Vianello, F.; Santinelli, V.; Maradonna, F.; Nozzi, V.; et al. Transfer of Silica-Coated Magnetic $\left(\mathrm{Fe}_{3} \mathrm{O}_{4}\right)$ Nanoparticles through Food: A Molecular and Morphological Study in Zebrafish. Zebrafish 2014, 11, 567-579. [CrossRef] [PubMed]

65. Alsop, D.; Wood, C.M. Metal Uptake and Acute Toxicity in Zebrafish: Common Mechanisms across Multiple Metals. Aquat. Toxicol. 2011, 105, 385-393. [CrossRef]

66. Dai, Y.J.; Jia, Y.F.; Chen, N.; Bian, W.P.; Li, Q.K.; Ma, Y.B.; Chen, Y.L.; Pei, D.S. Zebrafish as a Model System to Study Toxicology. Environ. Toxicol. Chem. 2014, 33, 11-17. [CrossRef]

67. Bhuvaneshwari, R.; Rajendran, B. Histopathological Alterations in Muscle, Liver and Gill Tissues of Zebra Fish Danio rerio Due to Environmentally Relevant Concentrations of Organochlo rine Pesticides (OCPs) and Heavy Metals. Int. J. Environ. Res 2015, 9, 1365-1372.

68. Hu, J.; Liu, J.; Li, J.; Lv, X.; Yu, L.; Wu, K.; Yang, Y. Metal Contamination, Bioaccumulation, ROS Generation, and Epigenotoxicity Influences on Zebrafish Exposed to River Water Polluted by Mining Activities. J. Hazard. Mater. 2021, 405, 124150. [CrossRef]

69. Lacave, J.M.; Bilbao, E.; Gilliland, D.; Mura, F.; Dini, L.; Cajaraville, M.P.; Orbea, A. Bioaccumulation, Cellular and Molecular Effects in Adult Zebrafish after Exposure to Cadmium Sulphide Nanoparticles and to Ionic Cadmium. Chemosphere 2020, 238, 124588. [CrossRef]

70. Hallare, A.V.; Schirling, M.; Luckenbach, T.; Köhler, H.R.; Triebskorn, R. Combined Effects of Temperature and Cadmium on Developmental Parameters and Biomarker Responses in Zebrafish (Danio rerio) Embryos. J. Therm. Biol. 2005, 30, 7-17. [CrossRef]

71. Favorito, R.; Chiarelli, G.; Grimaldi, M.C.; de Bonis, S.; Lancieri, M.; Ferrandino, I. Bioaccumulation of Cadmium and Its Cytotoxic Effect on Zebrafish Brain. Chem. Ecol. 2011, 27, 39-46. [CrossRef]

72. Feng, C.; Pedrero, Z.; Gentès, S.; Barre, J.; Renedo, M.; Tessier, E.; Berail, S.; Maury-Brachet, R.; Mesmer-Dudons, N.; Baudrimont, M.; et al. Specific Pathways of Dietary Methylmercury and Inorganic Mercury Determined by Mercury Speciation and Isotopic Composition in Zebrafish (Danio rerio). Environ. Sci. Technol. 2015, 49, 12984-12993. [CrossRef] 
73. Hamdi, M.; Sanchez, M.A.; Beene, L.C.; Liu, Q.; Landfear, S.M.; Rosen, B.P.; Liu, Z. Arsenic Transport by Zebrafish Aquaglyceroporins. BMC Mol. Biol. 2009, 10, 104. [CrossRef]

74. Alsop, D.; Lall, S.P.; Wood, C.M. Reproductive Impacts and Physiological Adaptations of Zebrafish to Elevated Dietary Nickel. Comp. Biochem. Physiol. Part C Toxicol. Pharmacol. 2014, 165, 67-75. [CrossRef]

75. Gonzalez, P.; Baudrimont, M.; Boudou, A.; Bourdineaud, J.-P. Comparative Effects of Direct Cadmium Contamination on Gene Expression in Gills, Liver, Skeletal Muscles and Brain of the Zebrafish (Danio rerio). BioMetals 2006, 19, 225-235. [CrossRef]

76. Wang, X.; Liu, L.; Wang, X.; Ren, J.; Jia, P.; Fan, W. Influence of Humic Acid on Arsenic Bioaccumulation and Biotransformation to Zebrafish: A Comparative Study between As(III) and As(V) Exposure. Environ. Pollut. 2020, 256, 113459. [CrossRef]

77. Zarantoniello, M.; Zimbelli, A.; Randazzo, B.; Compagni, M.D.; Truzzi, C.; Antonucci, M.; Riolo, P.; Loreto, N.; Osimani, A.; Milanović, V.; et al. Black Soldier Fly (Hermetia illucens) Reared on Roasted Coffee by-Product and Schizochytrium Sp. as a Sustainable Terrestrial Ingredient for Aquafeeds Production. Aquaculture 2020, 518, 734659. [CrossRef]

78. Qiu, Y.W.; Lin, D.; Liu, J.Q.; Zeng, E.Y. Bioaccumulation of Trace Metals in Farmed Fish from South China and Potential Risk Assessment. Ecotoxicol. Environ. Saf. 2011, 74, 284-293. [CrossRef]

79. Mount, D.R.; Barth, A.K.; Garrison, T.D.; Barten, K.A.; Hockett, J.R. Dietary and Waterborne Exposure of Rainbow Trout (Oncorhynchus mykiss) to Copper, Cadmium, Lead and Zinc Using a Live Diet. Environ. Toxicol. Chem. Int. J. 1994, 13, 2031-2041. [CrossRef]

80. Monge-Ortiz, R.; Martínez-Llorens, S.; Lemos-Neto, M.J.; Falcó-Giaccaglia, S.L.; Pagán, M.J.; Godoy-Olmos, S.; Jover-Cerdá, M.; Tomás-Vidal, A. Growth, Sensory and Chemical Characterization of Mediterranean Yellowtail (Seriola dumerili) Fed Diets with Partial Replacement of Fish Meal by Other Protein Sources. Aquac. Rep. 2020, 18, 100466. [CrossRef]

81. Chemello, G.; Zarantoniello, M.; Randazzo, B.; Gioacchini, G.; Truzzi, C.; Cardinaletti, G.; Riolo, P.; Olivotto, I. Effects of Black Soldier Fly (Hermetia illucens) Enriched with Schizochytrium Sp. on Zebrafish (Danio Rerio) Reproductive Performances. Aquaculture 2022, 550, 737853. [CrossRef]

82. Annabi, A.; Said, K.; Messaoudi, I. Cadmium: Bioaccumulation, Histopathology and Detoxifying Mechanisms in Fish. Am. J. Res. Commun. 2013, 1, 62-79.

83. Zhang, Y.; Feng, J.; Gao, Y.; Liu, X.; Qu, L.; Zhu, L. Physiologically Based Toxicokinetic and Toxicodynamic (PBTK-TD) Modelling of $\mathrm{Cd}$ and Pb Exposure in Adult Zebrafish Danio rerio: Accumulation and Toxicity. Environ. Pollut. 2019, 249, 959-968. [CrossRef]

84. Romeo, M.; Siau, Y.; Sidoumou, Z.; Gnassia-Barelli, M. Heavy Metal Distribution in Different Fish Species from the Mauritania Coast. Sci. Total Environ. 1999, 232, 169-175. [CrossRef]

85. Francis, P.C.; Birge, W.J.; Bwxt, J.A. Effects of Cadmium-Enriched Sediment on Fish and Amphibian Embryo-Larval Stages. Ecotoxicol. Environ. Saf. 1984, 8, 378-387. [CrossRef]

86. Wu, Z.; Puigserver, P.; Andersson, U.; Zhang, C.; Adelmant, G.; Mootha, V.; Troy, A.; Cinti, S.; Lowell, B.; Scarpulla, R.C.; et al Mechanisms Controlling Mitochondrial Biogenesis and Respiration through the Thermogenic Coactivator PGC-1. Cell 1999, 98, 115-124. [CrossRef]

87. Harrison, S.E.; Klaverkamp, J.F. Uptake, elimination and tissue distribution of dietary and aqueous cadmium by rainbow trout (Salmo gairdneri richardson) and lake whitefish (Coregonus clupeaformis mitchill). Environ. Toxicol. Chem. 1989, 8, 87-97. [CrossRef]

88. Rehwoldt, R.; Karimian-Teherani, D. Uptake and Effect of Cadmium on Zebrafish. Bull. Environ. Contam. Toxicol. 1976, 15, 442-446. [CrossRef] [PubMed]

89. Illuminati, S.; Truzzi, C.; Annibaldi, A.; Migliarini, B.; Carnevali, O.; Scarponi, G. Cadmium Bioaccumulation and Metallothionein Induction in the Liver of the Antarctic Teleost Trematomus bernacchii during an On-Site Short-Term Exposure to the Metal via Seawater. Toxicol. Environ. Chem. 2010, 92, 617-640. [CrossRef]

90. Adhikary, J.; Maity, A.; Kumar Das, B.; Ghosh, S.; Jayati Adhikary, C.; Pal, P. Accumulation of Cadmium (Cd) and Lead (Pb) in Tissues of Rohu Fish (Labeo rohita) Collected from the Sewage-Fed Pond of Kolkata. J. Entomol. Zool. Stud. 2019, 7, 146-150.

91. Hu, S.; Han, J.; Yang, L.; Li, S.; Guo, Y.; Zhou, B.; Wu, H. Bioconcentration, Depuration and Toxicity of Pb in the Presence of Titanium Dioxide Nanoparticles in Zebrafish Larvae. Aquat. Toxicol. 2019, 214, 105257. [CrossRef]

92. International Lead Association (ILA). Lead in Aquatic Environments. 2019. Available online: https://www.ila-lead.org/userfiles/ file/aquatic_environment_report_v6_hi\%20res.pdf (accessed on 20 September 2021).

93. Nøstbakken, O.J.; Hove, H.T.; Duinker, A.; Lundebye, A.K.; Berntssen, M.H.G.; Hannisdal, R.; Lunestad, B.T.; Maage, A.; Madsen, L.; Torstensen, B.E.; et al. Contaminant Levels in Norwegian Farmed Atlantic Salmon (Salmo salar) in the 13-Year Period from 1999 to 2011. Environ. Int. 2015, 74, 274-280. [CrossRef]

94. Hannisdal, R.; Nøstbakken, O.-J.; Hove, H.T.; Lunestad, B.T.; Frøyland, L.; Madsen, L. Monitoring Program for Pharmaceuticals, Illegal Substances, and Contaminants in Farmed Fish. 2013. Available online: https://nifes.hi.no/wp-content/uploads/2013/0 1/9623rapportfor2012130801.pdf (accessed on 20 October 2021).

95. Nandi, S.; Srivastava, R.C.; Agarwal, K.M. Lead and Cadmium Accumulation in Fresh Water Fishes Labeo rohita and Catla catla. J. Environ. Res. Dev. 2012, 6, 748-752.

96. Gonzalez, P.; Dominique, Y.; Massabuau, J.C.; Boudou, A.; Bourdineaud, J.P. Comparative Effects of Dietary Methylmercury on Gene Expression in Liver, Skeletal Muscle, and Brain of the Zebrafish (Danio rerio). Environ. Sci. Technol. 2005, 39, 3972-3980. [CrossRef]

97. Kelly, B.C.; Ikonomou, M.G.; Higgs, D.A.; Oakes, J.; Dubetz, C.; Canada, O. Mercury and other trace elements in farmed and wild salmon from British Columbia, Canada. Environ. Toxicol. Chem. 2008, 27, 1361-1370. [CrossRef] 
98. Wiener, J.G.; Krabbenhoft, D.P.; Heinz, G.H.; Scheuhammer, M. Ecotoxicology of Mercury. In Handbook of Ecotoxicology; CRC Press: Boca Raton, FL, USA, 2003; pp. 409-443.

99. Korbas, M.; MacDonald, T.C.; Pickering, I.J.; George, G.N.; Krone, P.H. Chemical Form Matters: Differential Accumulation of Mercury Following Inorganic and Organic Mercury Exposures in Zebrafish Larvae. ACS Chem. Biol. 2012, 7, 411-420. [CrossRef]

100. Gentès, S.; Maury-Brachet, R.; Feng, C.; Pedrero, Z.; Tessier, E.; Legeay, A.; Mesmer-Dudons, N.; Baudrimont, M.; Maurice, L.; Amouroux, D.; et al. Specific Effects of Dietary Methylmercury and Inorganic Mercury in Zebrafish (Danio rerio) Determined by Genetic, Histological, and Metallothionein Responses. Environ. Sci. Technol. 2015, 49, 14560-14569. [CrossRef]

101. Zarantoniello, M.; Randazzo, B.; Gioacchini, G.; Truzzi, C.; Giorgini, E.; Riolo, P.; Gioia, G.; Bertolucci, C.; Osimani, A.; Cardinaletti, G.; et al. Zebrafish (Danio rerio) Physiological and Behavioural Responses to Insect-Based Diets: A Multidisciplinary Approach. Sci. Rep. 2020, 10, 10648. [CrossRef]

102. Balshaw, S.; Edwards, J.W.; Ross, K.E.; Daughtry, B.J. Mercury Distribution in the Muscular Tissue of Farmed Southern Bluefin Tuna (Thunnus maccoyii) Is Inversely Related to the Lipid Content of Tissues. Food Chem. 2008, 111, 616-621. [CrossRef]

103. Meador, J.P. Comparative Toxicokinetics of Tributyltin in Five Marine Species and Its Utility in Predicting Bioaccumulation and Acute Toxicity. Aquat. Toxicol. 1997, 37, 307-326. [CrossRef]

104. Zhang, W.; Huang, L.; Wang, W.X. Arsenic Bioaccumulation in a Marine Juvenile Fish Terapon jarbua. Aquat. Toxicol. 2011, 105, 582-588. [CrossRef]

105. Zhang, W.; Huang, L.; Wang, W.X. Biotransformation and Detoxification of Inorganic Arsenic in a Marine Juvenile Fish Terapon jarbua after Waterborne and Dietborne Exposure. J. Hazard. Mater. 2012, 221-222, 162-169. [CrossRef] [PubMed]

106. Edmonds, J.S.; Shibata, Y.; Francesconi, K.A.; Rippingale, R.J.; Morita, M. Arsenic Transformations in Short Marine Food Chains Studied by HPLC-ICP MS. Appl. Organometal. Chem 1997, 11, 281-287. [CrossRef]

107. Azizur Rahman, M.; Hasegawa, H.; Peter Lim, R. Bioaccumulation, Biotransformation and Trophic Transfer of Arsenic in the Aquatic Food Chain. Environ. Res. 2012, 116, 118-135. [CrossRef]

108. Jankong, P.; Chalhoub, C.; Kienzl, N.; Goessler, W.; Francesconi, K.A.; Visoottiviseth, P. Arsenic Accumulation and Speciation in Freshwater Fish Living in Arsenic-Contaminated Waters. Environ. Chem. 2007, 4, 11-17. [CrossRef]

109. Kim, J.H.; Kang, J.C. The Arsenic Accumulation and Its Effect on Oxidative Stress Responses in Juvenile Rockfish, Sebastes schlegelii, Exposed to Waterborne Arsenic $\left(\mathrm{As}^{3+}\right)$. Environ. Toxicol. Pharmacol. 2015, 39, 668-676. [CrossRef]

110. Pei, J.; Zuo, J.; Wang, X.; Yin, J.; Liu, L.; Fan, W. The Bioaccumulation and Tissue Distribution of Arsenic Species in Tilapia. Int. J. Environ. Res. Public Health 2019, 16, 757. [CrossRef]

111. Bordajandi, L.R.; Gómez, G.; Fernández, M.A.; Abad, E.; Rivera, J.; González, M.J. Study on PCBs, PCDD/Fs, Organochlorine Pesticides, Heavy Metals and Arsenic Content in Freshwater Fish Species from the River Turia (Spain). Chemosphere 2003, 53, 163-171. [CrossRef]

112. Komjarova, I.; Blust, R. Multimetal Interactions between $\mathrm{Cd}, \mathrm{Cu}, \mathrm{Ni}, \mathrm{Pb}$, and $\mathrm{Zn}$ Uptake from Water in the Zebrafish Danio rerio. Environ. Sci. Technol. 2009, 43, 7225-7229. [CrossRef]

113. Ptashynski, M.D.; Klaverkamp, J.F. Accumulation and Distribution of Dietary Nickel in Lake Whitefish (Coregonus clupeaformis). Aquat. Toxicol. 2002, 58, 249-264. [CrossRef]

114. Lawrence, C.; Adatto, I.; Best, J.; James, A.; Maloney, K. Generation Time of Zebrafish (Danio rerio) and Medakas (Oryzias latipes) Housed in the Same Aquaculture Facility. Lab. Anim. 2012, 41, 158-165. [CrossRef]

115. Illuminati, S.; Annibaldi, A.; Truzzi, C.; Scarponi, G. Recent Temporal Variations of Trace Metal Content in an Italian White Wine. Food Chem. 2014, 159, 493-497. [CrossRef]

116. Morgano, M.A.; Milani, R.F.; Perrone, A.A.M. Determination of Total Mercury in Sushi Samples Employing Direct Mercury Analyzer. Food Anal. Methods 2015, 8, 2301-2307. [CrossRef]

117. Daniel, W.W.; Cross, C.L. Biostatistics: A Foundation for Analysis in the Health Sciences, 10th ed.; John Wiley \& Sons: Hoboken, NJ, USA, 2013.

118. STATGRAPHICS Centurion 19 Software; Manugistics Inc.: Rockville, MD, USA, 2019. 